\title{
A KINETIKUS CSALÁDRAJZ (KINETIC FAMILY DRAWINGS) ALKALMAZÁSA A PSZICHODIAGNOSZTIKÁBAN
}

\author{
VASS ZOLTÁN
}

ELTE, Személyiség- és Egészségpszichológiai Tanszék

E-mail: vasszolt@westel900.net

\begin{abstract}
A tanulmány a kinetikus családrajz (Kinetic Family Drawings, KFD) klinikai alkalmazásának hazai tapasztalatairól számol be azzal a céllal, hogy elösegitse a módszer beépülését a hazai klinikai pszichológia, gyermekpszichológia és -pszichiátria eszköztárába. A családrajz történetének és típusainak áttekintése után a kinetikus családrajz technikáját mutatja be, majd bevezetést nyújt az értelmezés folyamatá$b a$, ismertetve a szerzö gyakorlatában leghasznosabbnak talált értelmezési szempontokat. A kinetikus családrajz alkalmazását egy esettanulmány illusztrálja, melyben a családrajz többféle típusa (hagyományos családrajz, kinetikus családrajz és kinetikus állatcsaládrajz) is összehasonlításra kerül. A tanulmányt a kinetikus családrajz pszichometriai értékelése (reliabilitás és konstruktvaliditás), valamint a kutatási perspektívák áttekintése zárja, amelyben a szerzö elkülöníti a kinetikus családrajz kétféle használati módját: hipotézisgeneráló eszköz és pszichometriai értelemben vett teszt. Az elöbbi értelemben a kinetikus családrajz szerepe a klinikus számára pszichodiagnosztikai hipotézisek megalkotása, amelyek további igazolást kívánnak. Szigorú értelemben vett tesztként az alapvetö moderátorváltozókat figyelembe vevö normák kialakitására és további, jól megtervezett reliabilitás-, illetve validitásvizsgálatokra van szükség. Ez utóbbiak legfontosabb alapelvei az objektív, reprodukálható értékelési módszer használata, a globális-holisztikus elemzés, valamint az egyedi grafikus jegyek helyett a komplex mintázatok feltérképezése. A tanulmány konklúziója szerint a kinetikus családrajz megitélése pozitín a nemzetközi szakirodalomban: a módszer jól alkalmazható a klinikumban és a kutatásban egyaránt.
\end{abstract}

Kulcsszavak: $\quad$ pszichodiagnosztika, rajzvizsgálat, projektív rajzok, családrajz, gyermekrajz

A kinetikus családrajz (Kinetic Family Drawings, KFD; Burns, Kaufman, 1970) projektív rajzvizsgálati módszer, amely a gyermek-pszichodiagnosztikában, tanácsadásban, családterápiában, továbbá serdülők és felnőttek pszichológiai és pszichiátriai vizsgálatában alkalmazható. A módszer külföldön egyre inkább átveszi a hagyományos családrajz helyét, értelmező kézikönyveket publikálnak róla, a pszicho- 
metriai validitást alátámasztó empirikus eredmények és elismerő recenziók jelennek meg, itthon azonban még kevéssé épült be a pszichológiai tesztek repertoárjába. A szerző szeretné a szakma figyelmébe ajánlani a módszert, beszámolva a kinetikus családrajz (és a kinetikus állatcsaládrajz) klinikai alkalmazásával kapcsolatos néhány hazai tapasztalatról ${ }^{1}$ is, elősegítve ezzel a módszer beépülését a hazai klinikai pszichológia, gyermekpszichológia és -pszichiátria eszköztárába. Ehhez a családrajz típusainak és történetének áttekintése után ismerteti a kinetikus családrajz technikáját, majd bevezet a KFD értelmezési folyamatába. A gyakorlati alkalmazást egy esettanulmány illusztrálja, összehasonlítva egymással a hagyományos családrajz, a kinetikus családrajz és a kinetikus állatcsaládrajz értelmezésének tanulságait. A tanulmányt végül a kinetikus családrajz pszichometriai értékelése (a reliabilitás, a konstruktvaliditás és a kutatási módszertan áttekintése) zárja.

\section{A CSALÁDRAJZ TÍPUSAI ÉS TÖRTÉNETE}

A kinetikus családrajz a család lerajzoltatásának egy viszonylag új, Amerikában gyakran alkalmazott, hazánkban (ső́t Európában: lásd SCHETTY, 1974) kevéssé elterjedt változata. A családrajznak sokféle változata ismeretes, valamennyiük közös nevezője azonban három típus: 1. a saját család rajza, 2. egy (másik) család rajza, 3. egy megváltoztatott család rajza.

Időrendben haladva, az első csoport jelent meg a legkorábban. Az irodalom elsőként 1937-es évszámmal Trude Traube nevét említi, majd a francia Minkowskát, aki nemcsak a saját családot, hanem a gyermeket magát és a saját házat is lerajzoltatta (WIDLÖCHER, 1965). Az angolszász szakirodalom általában HULSE (1951, 1952) tanulmányát nevezi meg úttörőként Draw-A-Family (DAF) néven. Hulse a gyermekpszichiátriai első interjú megkönnyítéséhez kérte a gyermektől egy szabadrajz után saját családja rajzát. Önálló értelmezést keveset közöl, inkább esettanulmányokat olvashatunk tőle. Elsősorban GOODENOUGH (1926) és MACHOVER (1949) emberrajz-értelmezéseiből indult ki, hangsúlyozva a rajz egészének Gestaltként történő megragadását és a pszichoanalitikus szimbólumértelmezést.

A családrajz a megjelent publikációkból ítélve nagyobb figyelmet kapott Franciaországban és Németországban, mint az Egyesült Államokban. POROT (1965) a saját családot rajzoltatta le, Borelli-Vincent (1965), illetve CrocQ és Suziot (1968) először egy család, majd a saját család rajzát kérte, és a kettőt összehasonlította egymással.

A franciáknál maradva, a családrajz történetéből ki kell emelnünk CORMAN (1964, 1965) munkáját. Corman az addigi „rajzold le a családodat” instrukció ${ }^{2}$ he-

\footnotetext{
1 A szerző köszönetét fejezi ki a XI. ker. Nevelési Tanácsadó vezetőjének, dr. Villányi Lenkének, aki lelkes bátorításával segítette a tanulmány megszületését, Póka Máriának, aki nem csak a klinikai adatgyüjtés révén, de a rajzok értelmezésével is részt vett a módszer kipróbálásában, valamint a Tanácsadó valamennyi munkatársának, akik tapasztalataikkal hozzájárultak a rajzok megértéséhez.
} 
lyett a „rajzolj egy családot, olyat, amilyet elképzelsz” (,dessin une famille, une famille de ton invention", CORMAN, 1965, 68.) formát javasolta, mert ez az instrukció szabadabb terepet enged a projekciónak, mint a saját család rajza. A tapasztalatok szerint a gyermek ezzel az instrukcióval is a saját, aktuális családját ábrázolja. Corman módszere igen tanulságos: a rajz befejezése után mindig megkéri a gyermeket, hogy meséljen arról a családról, amelyet rajzolt, megkérdezi, hol vannak a családtagok, és mit csinálnak ott. Megneveztet a gyermekkel a rajzon mindenkit, kikérdezi a figurák szerepét a családban, kéri a nemüket és az életkorukat. Corman szerint a beszélgetésben szerepelnie kell négy kérdésnek: ki a legkedvesebb ebben a családban, ki a legkevésbé kedves, ki a legboldogabb és a legkevésbé boldog (minden válasznál meg kell kérdezni az okot is). Végül azt is meg kell tudni, ki lenne a gyermek legszívesebben a lerajzolt családban.

SHEARN és RusSELL (1969) javaslata szerint nemcsak a gyermektől, hanem a szülőktőll is érdemes családrajzot kérni. A szerzők tapasztalatai szerint a rajzok összehasonlításakor a családi dinamika olyan elemei is előbukkannak, melyek az egyedi rajzokban nem jelennek meg. Hasonló gondolatmenetet találunk BIERMANN (1962) munkájában, aki a családi neurózis (a szülők gyermekkorából karakterneurózisként áthozott, az egész családot, így a gyermeket is bevonó neurózis) feltárásához tartja hasznos eszköznek a családrajzot.

SCHETTY (1974) munkáját azért kell megemlíteni, mert 8-10 éves gyermekek családrajzainak formai elemzésével empirikus módon gyűjtötte össze a neurotikus családrajzok grafikus ismérveit. A viselkedészavaros, tanulási problémákkal küzdő, neurotikus tünetekkel rendelkező gyermekek családrajzaiban az egészségesekkel szemben nem fordulnak elő olyan járulékos elemek, mint a nap, az ég, a virágok. A rajz egésze részletekben szegény, az emberalakok kevés specifikus részletet tartalmaznak. Gyakori a profilábrázolás, a család laza csoportba rendeződik a képen. A neurotikus gyermekek kevés színt használnak, kerülik a narancssárgát, jobban kedvelik viszont a lilát. A sötét árnyalatok kifejezéséhez a feketét használják, szemben a jól beilleszkedő gyermekekkel, akik a fekete helyett inkább a szürke színt használják erre a célra. Az alkalmazott színek általában véve kevéssé realisztikusak. Kevesebb teret használnak a papírlapon (kisebb lesz a rajz), gyakori a papír szélére szoruló figura és a talajvonal elhagyása. Az emberrajzban nagyobb méretű a fej, mint az egészséges gyermekeknél, nem rajzolják meg a kezet és az ujjakat, hiányzik a váll, és bizonytalanul ábrázoltak a lábfejek.

Németországban a francia szerzők munkáinak ismertetésén túl (pl. ABEGG, 1973) olyan könyvek is megjelentek, melyek önállóan továbbfejlesztették a módszert. Az állatcsalád (BREM-GRÄSER, 1957) mint projektív eljárás a nevelési és iskolapszichológiai tanácsadásban alakult ki; indirekt formájú családrajz, ahol a gyermek saját családját rajzolja meg állatok képében (,zeichne deine Familie in Tieren”, 11). Az elvarázsolt család (Kos, BIERMANN, 1973) hangsúlyozottan pszi-

\footnotetext{
2 A rajzvizsgálat eredményét alapvető́n meghatározza az alkalmazott instrukció: a minimális jelentésbeli árnyalatok is más tartalmat hívnak elö a vizsgált személybő́l. Mivel a hazai klinikai gyakorlatban sokféle, pontatlan fordítás terjedt el, valamennyi bemutatott rajztesztnél közlöm az eredeti instrukciókat is.
} 
choanalitikus értelmezési keretet használ, az eredeti családrajz-instrukció módosításának célja a tudattalan megszólítása, indirekt módon a cenzúra megkerülése. Az instrukció a következő: „Most egy kicsit álmodozunk. Biztosan ismersz meséket! Most csinálunk együtt egy saját mesét... képzeld el, hogy jön egy varázsló, és elvarázsol mindenkit egy családban, minden embert, kicsiket és nagyokat... itt egy papír és egy ceruza, rajzold le, mi történik!” („Wir wollen jetzt miteinander ein wenig dichten. Du kennst doch Märchen? Wir werden nun ein eigenes Märchen machen... Stell Dir vor, es kommt ein Zauberer und verzaubert eine Familie, und zwar alle Menschen dieser Familie, Große und Kleine... Da hast Du ein Blatt Papier und einen Bleistift, und nun zeichne, was da geschehen ist!", 15.)

A családrajzhoz hasonló szerepet töltenek be (a szakirodalomban sajnálatosan elhanyagolt) anya-gyermek rajzok (Mother-and-Child Drawing). Az anya-gyermek rajzot GILLESPIE (1989) a reprezentációs ábrázolási szintet már elért gyermekeknél javasolja, azzal az egyszerü instrukcióval, hogy „rajzolj egy anyát és egy gyermeket” („draw a mother and a child”, 166). Az értékelés egyik érdekes szempontja az anya és a gyermek grafikus hasonlósága vs. a figurák differenciálódása, amelyet a szerzô a tárgykapcsolat-elmélet keretében az én és a tárgy különválásának mutatójaként értelmez (figyelembe véve az életkort és az ábrázolási képességet). Az anyagyermek rajz célja az internalizált tárgyhoz füződő viszony tudattalan projekciója, a hasítás, a tagadás, a projektív identifikáció szerepének feltárása, fóként Mahler szeparációs-individuációs elméletére támaszkodva. Egy másik módszer KAISER (1996) javaslata, aki a családi relációk, a korai kötődés vizsgálatának egy indirekt módszereként madárfészket rajzoltat (Bird's Nest Drawing, BND). A szimbólum felszólító jellege a korai anya-gyerek kapcsolat, pontosabban a biztos és a bizonytalan kötődés tudattalan projekciója. Az értelmezés olyan támpontok szerint történik, mint a fészek üressége vs. tojások vagy fiókák jelenléte; a levegőben lebegő vagy a fán biztonságosan ülő fészek; az anyamadár jelenléte; van-e alja a fészeknek; hézagos-e a fészek, ki tud-e esni belőle a tojás.

A magyar nyelvű családrajz-irodalomból HARSÁNYI (1968), FEUER (1992) és HALÁsZ (1993) hiánypótló munkáit kell kiemelni.

\section{A CSALÁDRAJZ EGY ÚJ VÁLTOZATA: A KINETIKUS CSALÁDRAJZ (KINETIC FAMILY DRAWING, KFD)}

A családrajz fentebb áttekintett válfajai közösek abban, hogy a családot statikusan ábrázolják. BURNS és KAUFMAN 1970-ben egy látszólag apró módosítást vezetett be az instrukcióba, megkérve a gyermekeket, hogy azt ábrázolják, amint a családtagok éppen valamilyen cselekvést végeznek. Az eredmény „a család dinamikájának meglepöen sokatmondó ábrázolása, tiszta képet rajzolva a családtagok interakcioiról és érzelmi kapcsolatairól" (HANDlER, HABENICHT, 1994, 441). A módszer termékenységét jól tükrözi Ames véleménye, aki szerint „ritkaság, hogy egy teszt ilyen gyorsan és biztosan mondjon ilyen sokat a vizsgált személyról" (AMEs, 1972). A kinetikus családrajzban a gyermek kifejezi, hogyan érzi magát a családi környezetben, hogyan észleli, jele- 
níti meg belső világában önmagát és a családot - amely alapvetően meghatározza személyiségfejlődését, attitüdjeit, bizalmát a világban.

A kinetikus családrajz kb. 5 éves kortól kezdve használható. Nem csak gyermekek, hanem serdülők és felnőttek projektív tesztvizsgálatára is alkalmas (például Wright és McIntyre depresszióskálája, lásd alább). Beilleszthető a nevelési tanácsadókban, pszichológiai, pszichiátriai, pszichoterápiás rendelőkben folyó klinikai interjúba, explorációba, jól kiegészíti a gyermek-pszichoterápia, a tanácsadás vagy a családterápia eszköztárát. Többféle célra is alkalmas:

a) mint általában a rajztesztek, oldhatja a gyermek helyzeti szorongását, mivel a rajzolás a gyermek számára ismerős, megszokott tevékenység;

b) modellreakcióként mutatja a gyermek viselkedését egy új, félig strukturált helyzetben;

c) projektív technikaként a személyiség olyan rétegeit képezi le, amelyek másként nehezen feltárhatók;

d) kisebb gyerekeknél, akik még nehezen fogalmaznak szavakkal, helyettesíti a verbális közlést;

e) amikor a raport nem elég mély, nemcsak helyettesíti, de hitelesítheti vagy meg is kérdőjelezheti a verbális közlést;

f) az ábrázolás aktuális tartalmán túlmutató, mélyebb klinikai interjú bevezetéseként, közvetítő közegeként alkalmazva átmenetet, keretet képez az éninvolváltabb kérdések megbeszéléséhez;

g) longitudinális rajzvizsgálati módszerként (részletesen lásd HÁRDI, 1983) használva alkalmas a pszichoterápia vagy a tanácsadás során a terápiás változások követésére, azok objektiválására;

h) végül specifikus produkciós felülete lehetővé teszi annak vizsgálatát, hogyan észleli a gyermek a családtagok, a referenciacsoport és a számára fontos, más személyek interakcióit, viszonyulását egymáshoz.

Mint általában a rajzvizsgálati eljárások, a kinetikus családrajz is tekinthető pszichometriai értelemben vett tesztnek, illetve heurisztikus hipotézisgeneráló eljárásnak. Mindkét megközelítésnek vannak hívei és ellenzői, a két nézet ütköztetése heves irodalmi vitákat eredményez (áttekinti VASs, 1999c). A szerző álláspontja szerint a projektív rajzok megfelelő alkalmazási módja a rendszerszemléletű elemzés (részletesen lásd erröl SEHRINGER, 1983, 1989, 1999; VASs, 2000b, 2000c, 2000d). Ehhez egyéni tesztfelvétel szükséges, mert a grafikus adatokat ki kell egészíteni viselkedéses, verbális és anamnesztikus adatokkal, figyelembe kell venni a rajzolás folyamatváltozóit és a legfontosabb moderátorváltozókat. Másként fogalmazva, a rajzba először bele kell vinnünk előzetes ismereteket, hogy aztán több, gazdagabb, mélyebb információt olvashassunk ki belőle (HAMMER, 1969; VASs, megjelenés alatt).

BURNS és KAUFMAN (1972) a kinetikus családrajzot egy másik rajzteszttel, a Prout és PHILlips (1974) által kidolgozott kinetikus iskolarajzzal (Kinetic School Drawing, KSD) együtt alkalmazza (Kinetic Drawing System). A kinetikus iskola- 
rajzban a gyermek iskolát rajzol, benne saját magával, a tanárral és egy vagy két baráttal úgy, hogy mindenki csináljon valamit. (,I'd like you to draw a school picture. Put yourself, your teacher, and a friend or two in the picture. Make everyone doing something. Try to draw whole people and make the best drawing you can. Remember, draw yourself, your teacher, and a friend or two, and make everyone doing something”, KNOFF, ProUT, 1985, 4.) A kinetikus iskolarajz célja az iskolával, az autoritással, a teljesítménnyel, a kortárskapcsolatokkal összefüggő konfliktusok feltárása. Az értelmezés nagyrészt a kinetikus családrajz értelmezési támpontjait öleli fel, kiegészítve néhány specifikus interakcióval. A jelen tanulmány a kinetikus iskolarajzzal bővebben nem foglalkozik.

\section{A KINETIKUS CSALÁDRAJZ TECHNIKÁJA}

A kinetikus családrajzot legtöbbször kétszemélyes helyzetben vesszük fel. Mint általában a rajzok, alkalmas arra is, hogy az exploráció elején - félig strukturált, ismerôs feladatként - oldja a gyermek szituatív szorongását (ezt az aspektust már HULSE is hangsúlyozza 1951-ben a családrajz bevezetésének egyik indokaként). Közvetlenül a Rorschach-teszt előtt ne vegyük fel, mert olyan válaszhajlamot alakíthat ki, amely a formaválaszokra vagy a mozgásra irányítja a gyermek figyelmét. Ha más rajzteszttel együtt használjuk (például szabadrajz, emberrajz, farajz, állatrajz, családrajz, elvarázsolt család), akkor először ezeket rajzoltassuk meg, és csak utána kérjük a kinetikus családrajz elkészítését (a semlegesebb, egyszerủbb instrukciókat kövessék a specifikusabb, komplexebb feladatok).

A rajzvizsgálatot „B” vagy „2B” jelzésű ceruzával végezzük, a családrajznál megszokott, DIN A4-es formátumú, fehér papírlapot (gépírólap, fénymásoló papír) használva. A lapot a vizsgált személy elé fektetve tesszük le, de ő a papírt szabadon elforgathatja. BURNs és KAUFMAN (1972) instrukciójában a radír használata is megengedett. Az értelmezéshez fontos támpont a szukcesszió (az ábrázolási sorrend), a radírozások száma és helye, valamint a gyermek nonverbális viselkedése rajzolás közben (például impulzivitás, tervszerüség, arckifejezés, motiváció; a rajzok folyamatelemzéséről lásd SEHRINGER, 1983, 1989, 1999).

BURNS és KAUFMAN (1972) instrukciója eredetileg a következőképpen hangzik: „Rajzolj le mindenkit a családodból, beleértve magadat is, amint csinál valamit. Próbálj meg egész embereket rajzolni, ne rajzfilmfigurákat vagy pálcikaembereket. Tehát mindenki csináljon valamit - végezzen valamilyen cselekvést.” („Draw a picture of everyone in your family, including you, DOING something. Try to draw whole people, not cartoons or stick figure. Remember, make everyone DOING something-some kind of action”, 5.) A többi projektív rajzteszt instrukciójával összevetve Burns instrukciója feleslegesen bonyolultnak és a projekciós folyamatot korlátozónak tünhet. Értelmezhető például a pálcikaember megjelenése (HÁRDI, SAÁGHY, 1982; HÁRDI, 1983 ) vagy a saját alak kihagyása is. Egy projektív tesztben minél kevésbé specifikus a hívóinger, annál nagyobb lesz a válasz szabadságfoka, annál nagyobb tér jut a válasz projektív tartalmai számára (SEHringer, 1983; AbraHAM, 1991). Saját 
használatunkban ezért neutrálisabb formát alakítottunk ${ }^{3}$ ki: „,Rajzold le a családodat úgy, hogy mindenki csináljon valamit." Ha a gyermek magát kihagyja a rajzból, feljegyezzük, és megkérjük, hogy rajzolja le saját magát is. A kérdésekre nem irányító, semleges válasszal felelünk.

Miután elkészült a rajz, megkérdezzük a gyermektől, kit rajzolt le, hány évesek az ábrázolt alakok és - fóként - mit csinálnak. Adott esetben érdemes feltenni a ház-, fa-, emberrajz tesztben használatos kérdések közül néhányat: mit csinált az ábrázolt személy a lerajzolt cselekvés elött, mit fog csinálni késöbb, mi a jó benne, mi a rossz benne, mit érez, mire vágyik, mire van a leginkább szüksége (VAss, 1996a). Megkérdezhetjük azt is, hogy ha a gyermek valamit meguáltoztathatna a családrajzon, vajon mi lenne az; végül érdemes megkérdezni a gyermektől, vajon szívesen él-e ebben a családban (O'Brien, Patton, 1974).

\section{A KINETIKUS CSALÁDRAJZ ÉRTELMEZÉSE}

A kinetikus családrajz értelmezésére is érvényesek mindazok az alapelvek, amelyeket a projektív rajzok értelmezésekor figyelembe kell venni. Ezek közül a legfontosabbak az egyedi ismérvek (szótárszerü elemzés) helyett az ismérvek konzisztens mintázatainak (egymást támogató grafikus jegyek) keresése, a globális rajzi színvonal figyelembevétele, az elemzési kontextus kibővítése, az összehasonlító elemzés és az objektív mérések használata (SEHringer, 1983, 1999; VASs, 1996b, 1999c, 2000d; HÁRDI és munkatársai, 2000).

BuRns és KaUfMAN (1972; lásd még BuRns, 1982) közel 10000 gyermekrajz feldolgozásával alakították ki elemzési rendszerüket. A kinetikus családrajz értelmezéséhez háromfázisú elemzést javasolnak:

1. Globális értékelés: a rajz érzelmi tónusának, ${ }^{4}$ globális színvonalának értékelése, továbbá a feltűnő cselekvések, szokatlan grafikus jegyek elemzése.

2. Az emberalakok értékelése: a tárgyakat figyelmen kívül hagyva, az emberalakok interakcióinak, cselekvéseinek és rajzi jegyeinek elemzése.

3. A tárgyak értékelése: az embereket gondolatban kihagyva, csak a tárgyak pozícióját, hangsúlyozását, használatát elemezzük.

${ }^{3}$ Köszönöm dr. Szakács Katalinnak, hogy számos konstruktív javaslata mellett arra is felhívta a figyelmem, hogy a KFD eredeti instrukciója, amely a saját család rajzát kéri, korlátozhatja a projekció szabadságát. A tanulmány szerzője által is átvett megfogalmazás indoka egy folyamatban lévő empirikus vizsgálat (lásd 7. lábjegyzet), amelyben lényeges szempont a nemzetközi standardokkal való összehasonlíthatóság biztosítása.

4 Sokszor az egyszerủ leírás (a terapeuta leírása a rajzról) is megvilágít, tudatosít fontos jellemzóket. Érdemes néhány percig nézni a rajzot, befogadó attitủddel megengedve, hogy hasson ránk, majd leírni egy papírra azokat érzéseket, melyet a rajz számunkra kifejez. Ugyancsak hasznos a HÁRDI (1983) által leírt motoros empátia használata: egy papírlapon vagy egyszerủen csak becsukott szemmel kövessük végig, a levegőbe rajzolva reprodukáljuk, éljük újra a vonalat létrehozó mozdulatot. Ezek a módszerek különösen elősegítik a globális-intuitív megértést. 
A jól beilleszkedô, egészséges gyermekek rajzaiban általában fizikailag közel vannak egymáshoz a családtagok, interakcióban állnak, és a gyermek életkorának megfelelő színvonalon, közel azonos nívóval ábrázoltak. Legtöbbször megjelenik valamilyen fényforrás is, az anya gyakran tápláló jellegű tevékenységet végez (például fóz), és a teljes családi atmoszféra a békét, a bensőségességet sugározza (1. ábra). Általános negatív jelzések (2. ábra) az izoláció bármilyen megjelenése, az arctalanság, az elfordulás, a saját világba merülés a családdal való kapcsolat helyett, valamint a negatív érzelmeket (düh, szomorúság, elutasítás stb.) kifejező arckifejezés a legalább „d” rajzi személyiségszintet (HÁRDI, 1983) elérő rajzokban. A kinetikus családrajz értelmezésekor Burns és Kaufman öt szempontot emel ki: 1. cselekvések, 2. az emberrajz jellemzői, 3. elhelyezés, távolság és interakciós akadályok, 4. stílus és 5. szimbólumok. Az alábbiakban a saját tapasztalataink szerinti leggyakoribb, legfontosabb értelmezési támpontokat foglaljuk össze, elsősorban BuRns és KAUfMAN (1972), valamint KNOFF és PROUT (1985) munkáira támaszkodva. A szimbólumok értelmezését a szótárszerủ elemzés elkerülése miatt ebben a tanulmányban nem tárgyalom (részletesen lásd VASs, 2000e).

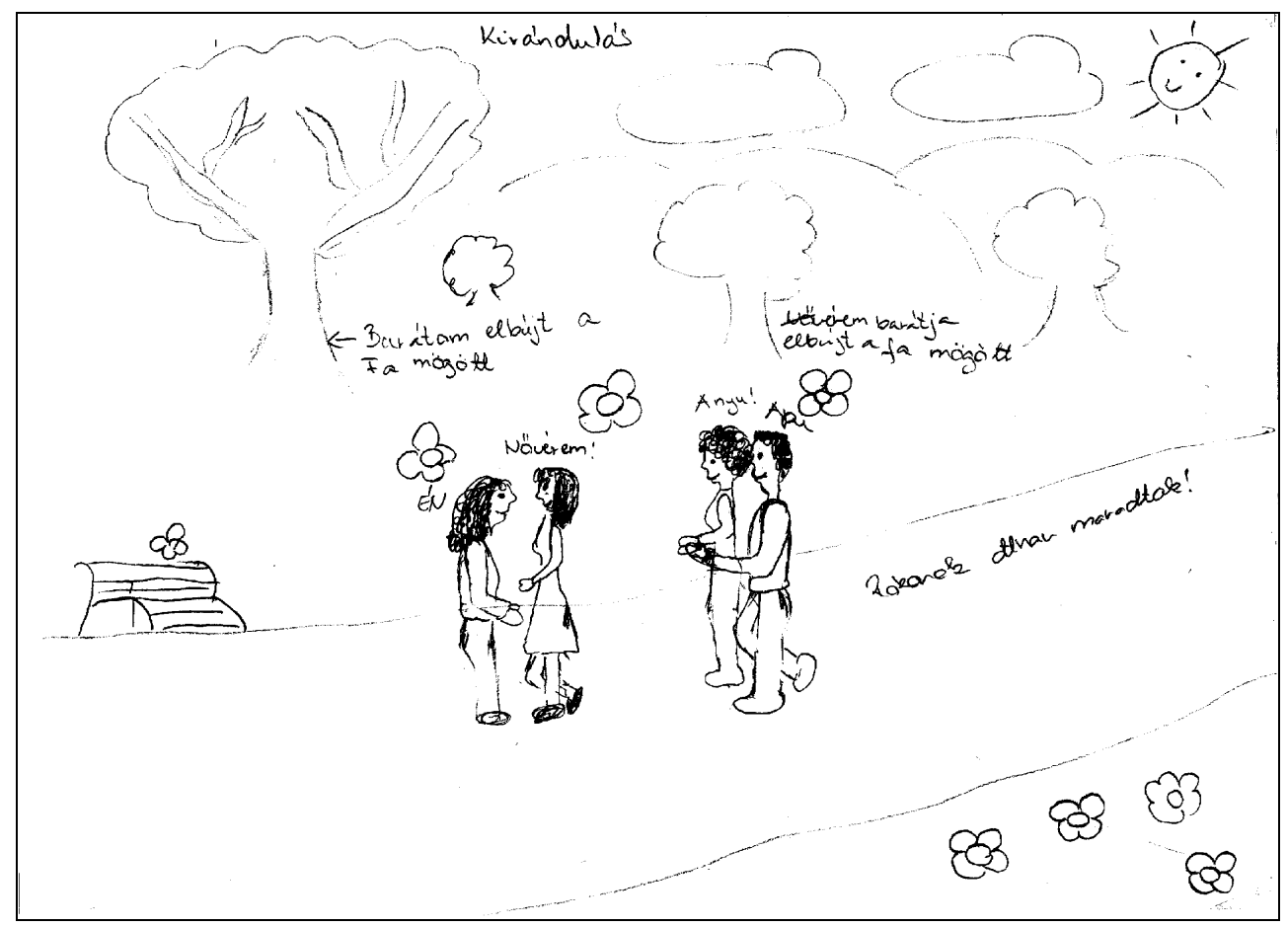

1. ábra. Globálisan pozitív kinetikus családrajz 


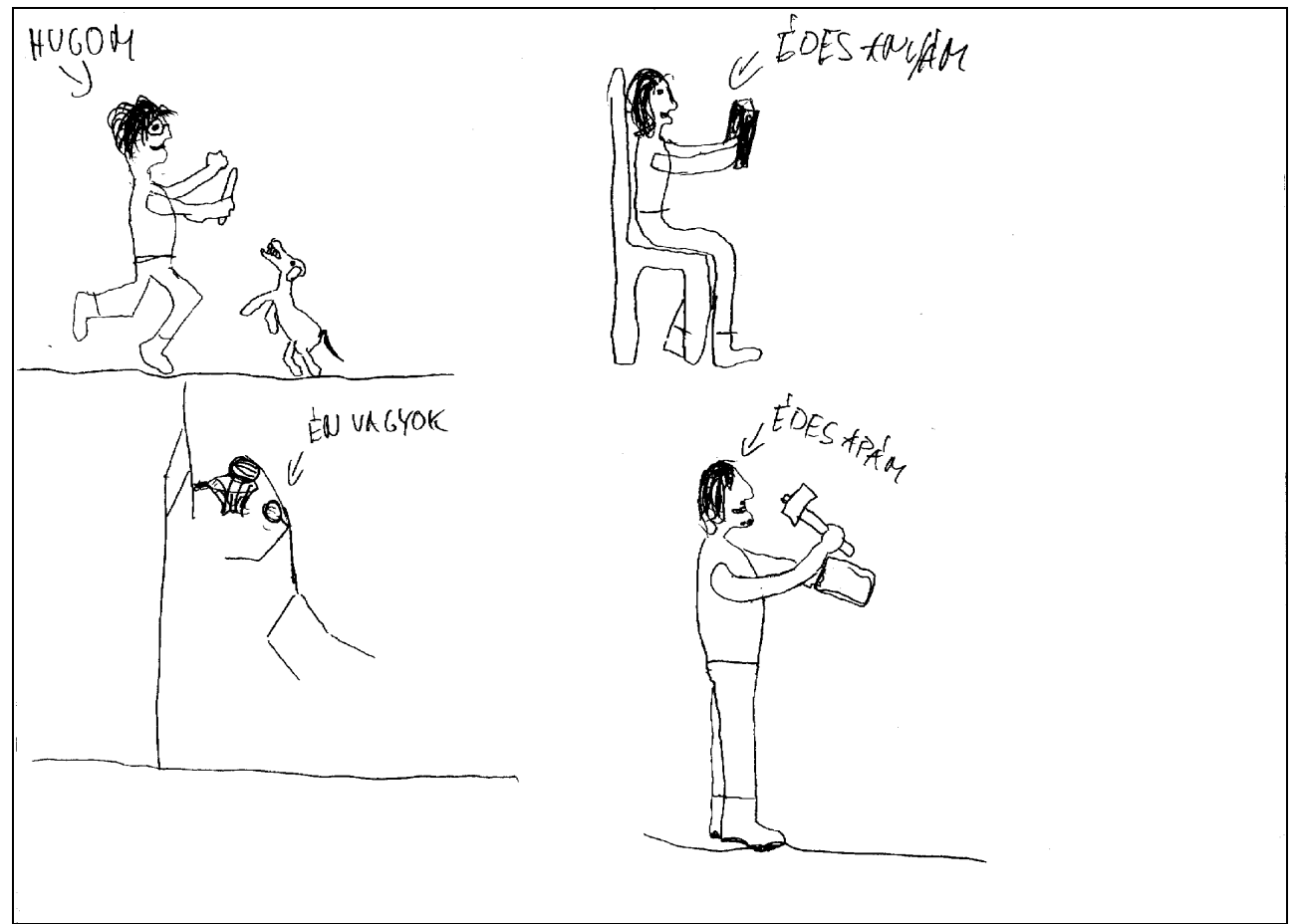

2. ábra. Negatív jelzések a kinetikus családrajzban

\section{Cselekvések}

A kinetikus családrajz cselekvéselemzése azon a metaforán alapul, hogy az emberek között egy közelebbről nem meghatározott „energiaáramlás” van. Ez az „energia” az idegenek között gyenge intenzitású, a nagyon közeli emberek között viszont erősebb intenzitású. Az „energia” összesűrűsödhet vagy szimbolizálódhat tárgyak formájában, mint például a labdázásban; vagy invesztálhatjuk bizonyos dolgokba, mint például a saját testbe (grafikus megjelenése a satírozás). Az „energia” áramlásának útjában azonban akadályok is állhatnak (rajzilag tárgyak, dolgok, vonalak a két személy között).

Labda, labdázás. Az egyik leggyakoribb cselekvés a kinetikus családrajzban a labdázás. A labdajátékok bizonyos esetekben rivalizálást vagy agressziót fejezhetnek ki a labdával játszó vagy a labdával térben elválasztott személyek között. A labda nagy mérete ebben az értelemben lehet a versengés igényének kifejezője. BURNs és KAUFMAN (1972) értelmezése szerint amikor a labda célzottan valaki felé irányul, a gyermek nem csak szeretne, de képes is versenyezni a személlyel; ezzel szemben ha elkerüli a célba vett személyt, a testhez tapad vagy felfelé irányul, akkor a gyermek nem tartja képesnek magát a versengésre. Amikor a rajzon mások játszanak, 
de a gyermek nem, féltékenységet gyaníthatunk a többiekkel szemben; ha viszont csak ő labdázik magányosan, akkor alkalmazkodási problémákra, szociális elszigeteltségre gondolhatunk. A fejre rajzolt labda ugyancsak szociális gátlásokat fejezhet ki. Amikor az egész család együtt labdázik, arra kaphatunk utalást, hogy a gyermek szívesen vesz részt konstruktív, kompetitív tevékenységekben.

Az anya cselekvései közül a leggyakoribb a fözés ábrázolása, melynek jelentése általában a gyermeket tápláló, szeretetét kifejező, a gyermek iránt gondoskodóként reprezentált anya. A takarítás motívuma sokszor olyan anyát ábrázol, akinek fontosabb a ház tisztasága, mint a családtagokkal való kapcsolat (az ilyen rajz sokszor kényszeres vonásokkal rendelkező anyát ábrázol). Vasaló anyát BURNS és KAUFMAN (1972) tapasztalatai szerint a nagy szeretetigénnyel rendelkező gyermekek rajzolnak; a vasalás az anyai melegséget jelképezi.

Dolgozó vagy autót vezető apát olyan gyermekek rajzában találhatunk, akiknek az édesapja perifériálisan tartozik a családhoz, érzelmileg a gyermek nem integrálja ôt a családba. Az autoriter vagy „kasztráló” édesapák sokszor valamit vágnak a rajzon (fünyírás, favágás stb.). A magas aktivitási szintűnek (futás, sportolás) ábrázolt apa a gyermek alacsony önértékelését jelezheti, míg a gyermek felé forduló apa rajza a magasabb önértékelésü, szociálisan és a kortárscsoportban jobban elfogadott gyermekek rajzában jelenik meg (lásd még az alábbiakban O'BRIEN és PATTON 1974-es eredményeit is).

\section{Az emberrajz jellemzöi}

A fogak, a különösen hegyesnek rajzolt ujjak vagy lábujjak agressziót és acting-out hajlamot jelezhetnek. A nagyon hosszú karok a saját személy rajzában mások elutasítását, az elzárkózás, a befelé fordulás igényét mutatják; ugyanez más alakokban a gyermeket elutasítóként vagy félelmetesként reprezentált személyt jelöli. A két személy között megjelenő, extrém hosszú karok a két személy rivalizálását ábrázolják. Az átfirkált, satírozott vagy nagyon sűrün árnyékolt figura az emocionális problémák jelenlétét mutatja. Amikor ez a jellegzetesség egy specifikus testrészen jelenik meg, az a testrész szimbolikus jelentéstartományával kapcsolatos szorongást, fixációt fejezi ki. Az erős satírozás azonban az egymással intenzív interakcióban lévő családtagokat is összekapcsolhatja; ha egy személyre vagy tárgyra összpontosul, akkor az adott személy vagy tárgy katexisét, a vele kapcsolatos szorongásokat jelzi. A saját személyen az arc üresen hagyása alacsony önértékelést jelez.

Soktagúként ábrázolt családot jó iskolai előmenetelű, pozitív énképpel rendelkező gyermekek rajzaiban találunk. A családtagok egymáshoz viszonyított magassága a családtagok szubjektív fontosságának vagy pszichológiai hatásának mutatója (a nagy méret együtt jár a nagyobb fontossággal). Ha a gyermek magát aránytalanul kisebbnek ábrázolja a többi családtagnál, ezzel kisebbértéküségi érzéseit, negatív énképét vetíti a papírlapra. Ha azonban nagyobbnak rajzolja magát, ezzel nem csak önértékeléséről (túlzott méretkülönbség esetén túlkompenzációról), de agressziójáról is árulkodhat. 
Amikor a saját alakot másik figurához hasonlónak (ruha, irányok, arckifejezés, formai jellemzók) ábrázolja a gyermek, akkor ezzel a másik személy fontosságát, a vele való identifikációt mutatja meg (amit a már említett anya-gyermek rajzok is megerősítenek).

Ha a saját alakot a papírlapon feljebb helyezi el, mint másokat, ezzel a dominancia igényét vagy a fokozott figyelem vágyát jelzi. Ha más személyt rajzol feljebb, az az adott személy dominanciáját reprezentálja.

A családtagok kihagyása általában az emocionális problémák jelzése; az egyes konkrét esetekben a kihagyott személy felé irányuló, manifesztációjában letiltott agressziót mutathatja (gyakran figyelhető ez meg az újszülött testvérnél). A saját alak kihagyása kisebbértékűségi érzéseket, negatív énképet, a gyermek periferiális családi pozícióját jelzi.

Amikor a gyermek minden alakot pálcikaemberként rajzol, fontos megtudnunk, hogy kérésre kiegészíti-e a rajzot. Ha igen, akkor valószínüleg tesztszorongás áll a válasz hátterében, ha nem, akkor a regresszióra mint stressz esetén preferált elhárító mechanizmusra gondolhatunk (vegyük azonban figyelembe, hogy pálcikaember alacsony IQ esetén is megjelenhet). Ha csak egy-egy személyt ábrázol pálcikaemberként a gyermek, az nem specifikus jegyként emocionális problémákat, specifikus értelemben pedig a reprezentált személlyel kapcsolatos szorongást, védekezést, dacot, szegényes érzelmi kapcsolatot jelzi.

A nem természetes alakok (robot, animalisztikus vonások) a realitásvizsgálat gyengeségét, bizarr formában ábrázolva nagyobb gyermekeknél és serdülóknél a gondolkodászavar, esetleg pszichózis lehetőségét vetik fel.

\section{Az elhelyezés és a térbeli távolságok értelmezése}

A saját alak közel rajzolása másik személyhez azt mutatja, hogy a gyermek szereti a reprezentált családtagot, szeretne közelebb kerülni hozzá, vagy több figyelmet igényel tőle (serdülőknél azonban már kevésbé működik ez a típusú projekció). Amikor a gyermek közel rajzolja magát a szülőhöz, ezzel a rá irányuló figyelem és elfogadás igényét, valamint az identifikációt ábrázolja; a távolság ezzel szemben az elszigeteltség és elutasítottság érzéseit jeleníti meg. A saját alak és az anya között lévő bármilyen fizikai akadály az anyától való pszichológiai távolságot reprezentálja.

A megnövelt figurák (például dobozokra helyezve) rivalizációt, dominanciaigényt jeleznek. Ha magát rajzolja nagyobbra a gyermek, ezzel gyakran azt a vágyát is kifejezésre juttatja, hogy idősebb szeretne lenni.

Ha a többiek egy csoportban vannak, a saját alak pedig távolabb kerül a csoporttól, akkor a gyermek olyannak észleli magát, mint aki nem tagja a csoportnak, akit kihagynak a közös dolgokból; együtt járhat ez érzelmi elzárkózással, az önelfogadás hiányával, a család általi elutasítottság érzésével, kialakulatlan társas készségekkel is. A két szülő közé rajzolt saját alak a túlzottan védett vagy több szülői figyelmet igénylő gyerekeknél fordul elő. Az interakciók hiánya (nem fordul egymás felé egyetlen alak sem, egymásnak oldalt vagy háttal forduló alakok, izolált interakciót végző alakok) a családon belüli kommunikáció szegényességére utal. Amikor a 
szülők nem lépnek interakcióba más alakokkal, a gyermek a szülők általi elutasítottságot érezhet. A saját alak elforgatása a családi beilleszkedés problémáit, az elutasítottság érzését vagy a figyelem igényét mutatja. A családtagok lerajzolási sorrendje általában az életkori sorrendet követi, ahol az emberalak mérete az életkorral együtt nő; az ettől eltérő sorrend a reprezentált személy relatív fontosságát jelzi.

\section{Formai jegyek, stílus}

Körülbelül hatéves kortól kezdődően a nagyon aszimmetrikus rajz impulzivitást, a túlzott részletezés vagy a tárgyak perszeverációja kényszerességet, bizonytalanságot, szokatlanul nagyra rajzolt fejjel együtt az intellektualizáció mint elhárító mechanizmus preferenciáját jelzi. A radírozás a reprezentált alakkal kapcsolatos ambivalenciát, konfliktust mutathatja.

A kompartmentalizáció a családtagok tudatos elhatárolása a lap teljes hosszán végigterjedő, egyenes vonalakkal, például dobozokba, téglalapokba rajzolás formájában (3. ábra). A kompartmentalizáció BURNS és KAUFMANN (1972) megfigyelései

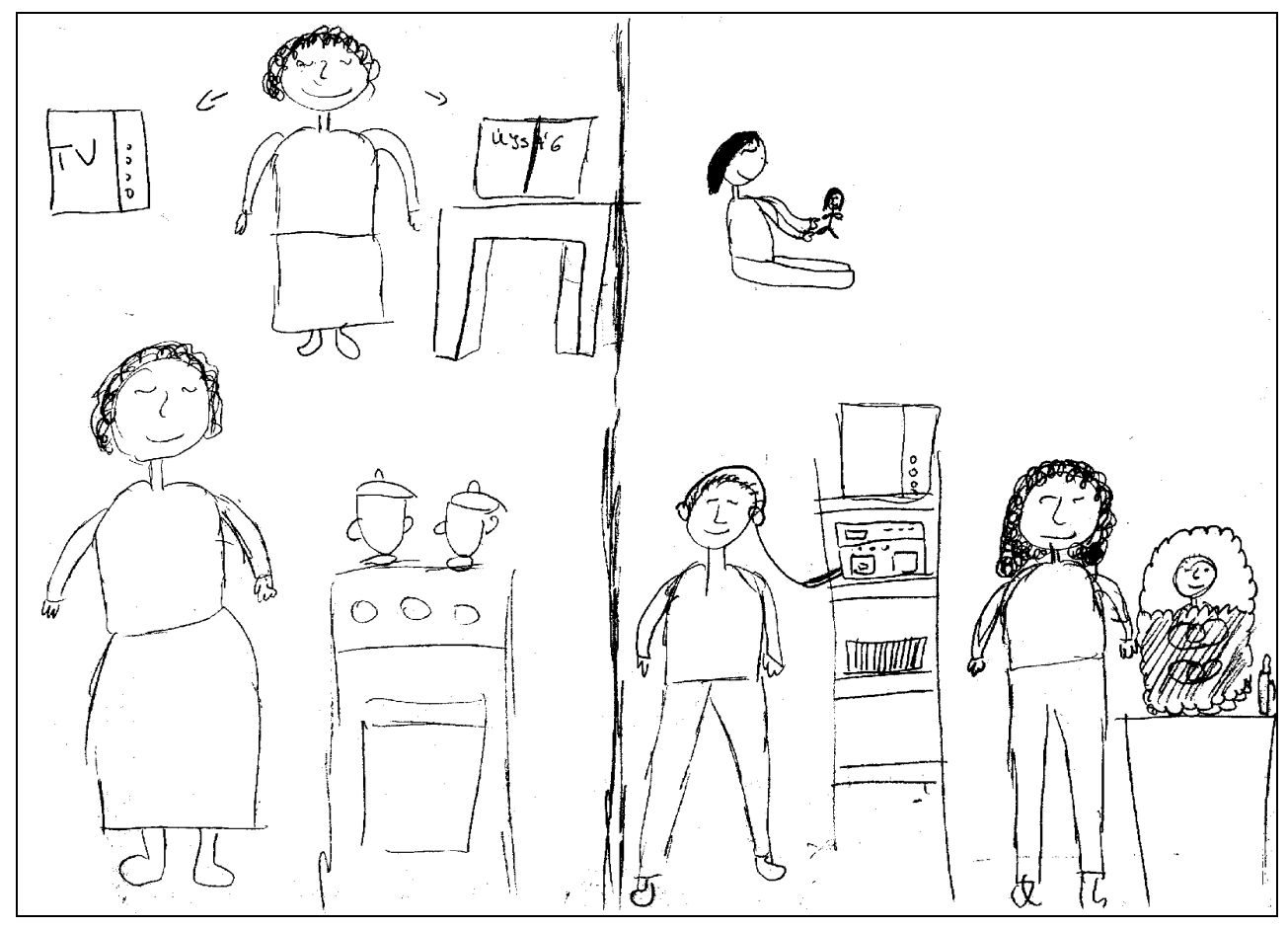

3. ábra. Kompartmentalizáció 
szerint a gyermek igényét mutathatja arra, hogy elhúzódjon, elhatárolja önmagát és érzéseit másoktól a családban (szociális izoláció; a szeretetet nem lehet nyíltan kifejezni). Mutathatja az elutasítottság érzését, a félelmet más családtagoktól, vagy a nyílt kommunikáció hiányát. Ha a kompartmentalizáció mellett minden családtag külön tevékenykedik a rajzon, az a család egységének hiányát, összetartozásának lazaságát jelzi. Amikor azonban két vagy több alakot határol körül a gyermek, ezzel inkább azt fejezi ki, hogy intenzíven foglalkoztatja ôt az ábrázolt személyek kapcsolata. Ritka, de markáns jegy a papírlap hajtogatásával létrehozott kompartmentalizáció: súlyos szorongásnál, akut érzelmi problémáknál jelenik meg. A kompartmentalizáció előfordulási gyakoriságát gyermekeknél, klinikai populációban BURNS és KAUFMAN (1972) 20,8\%-osnak, a papírlap hajtogatásával létrehozott kompartmentalizációét 2,1\%-osnak találta.

Az enkapszuláció megjelenésekor a gyermek néhány (de nem az összes) alakot határol körbe egy tárgy körkörös vonalaival (például ugrókötéllel, repülőgéppel, autóval), melyek nem terjednek végig a papírlap teljes hosszán (4. ábra). Ez a stílusjegy az érzelmi problémákkal küzdő gyermekek rajzaiban fordul elő, és az ábrázolt személyek kizárásának, eltávolításának vágyát mutathatja. Ha két személyt zár körbe ezen a módon a gyermek, azzal gyakran a köztük lévő szoros kapcsolatot ábrázolja. Az előfordulási gyakoriságot a már említett populációban BURNS és KAUFMAN (1972) 13\%-nak találta.

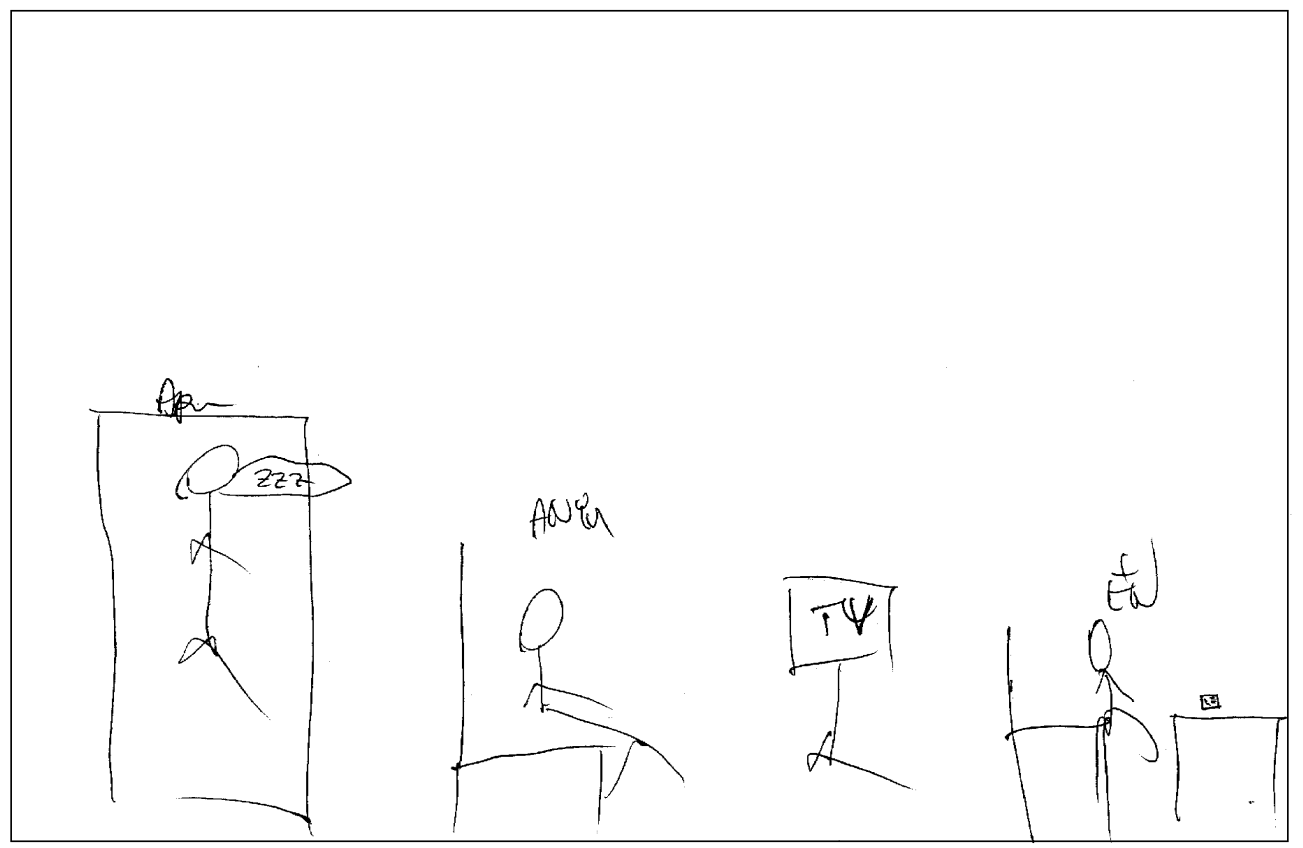

4. ábra. Enkapszuláció 
A papírlap felsö részének leválasztása egynél több, a lap teljes szélességén végighúzódó vonallal (még akkor is, ha ez felhő vagy valamilyen tárgy révén történik) akut szorongással, diffúz félelmekkel jár együtt. Ugyanez a lap alján (5. ábra) olyan gyermekek rajzaiban fordul elő, akik nehéz helyzetben levő, ingatag, bizonytalan családban élnek, ahol különösen fontossá válik a biztonság, a stabilitás szükséglete. Hasonló az értelmezése a kereszteződő vonalakkal besatírozott talajvonalnak is; minél szélesebb a besatírozott sáv és minél intenzívebb a satírozás, annál súlyosabb a zavar.

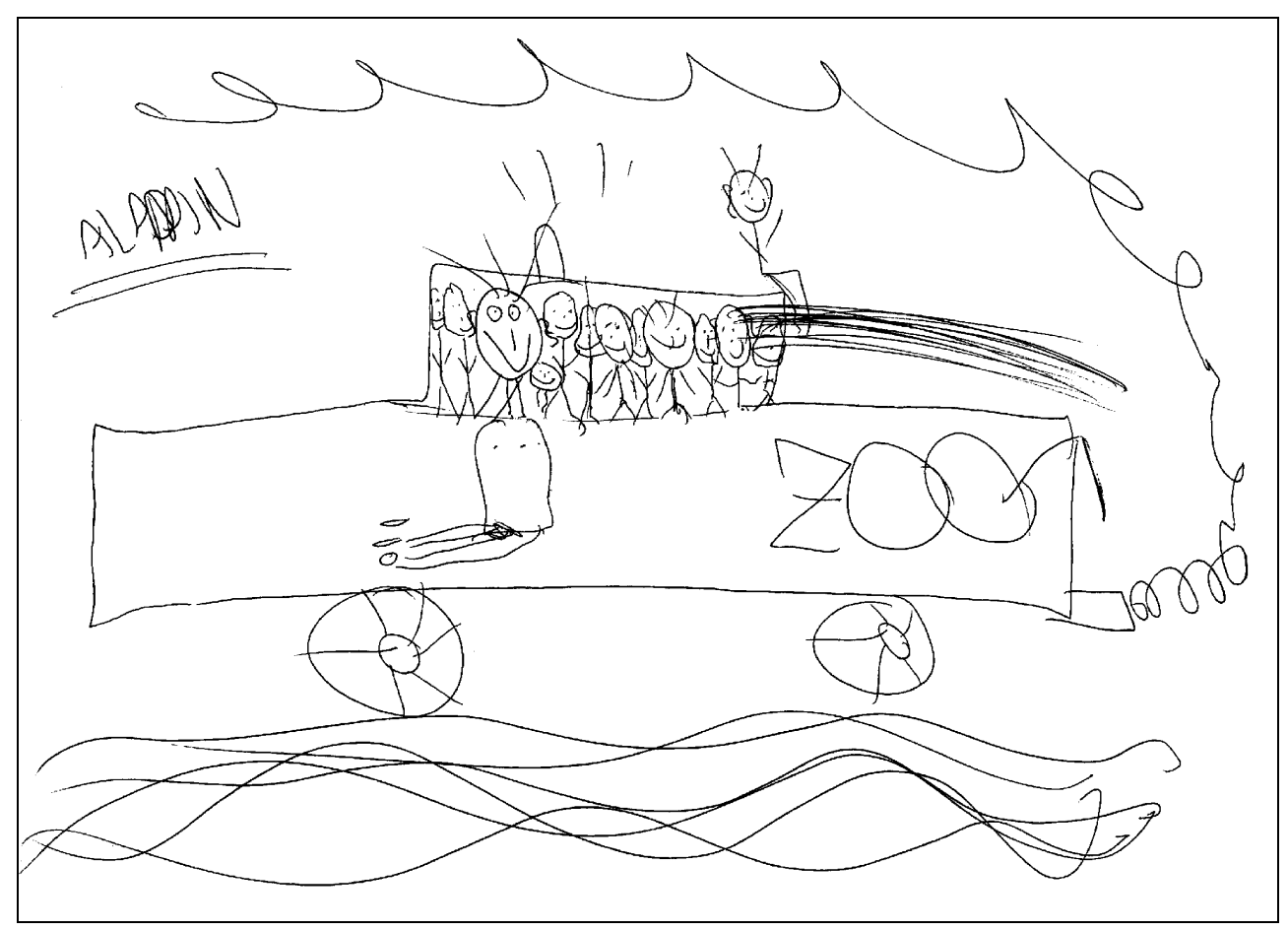

5. ábra. A lap alsó részének leválasztása

Az aláhúzott alakok (6. ábra; legalább két vonallal vagy ismétlődve aláhúzva) az ábrázolt személy és a gyermek ingatag, bizonytalan kapcsolatára utalnak. Az előfordulási gyakoriságokat BURNS és KAUFMAN (1972) a felső leválasztásnál 4,2\%-nak, az alsó leválasztásnál 12\%-nak, és az aláhúzott alakoknál 9,9\%-nak találta. 


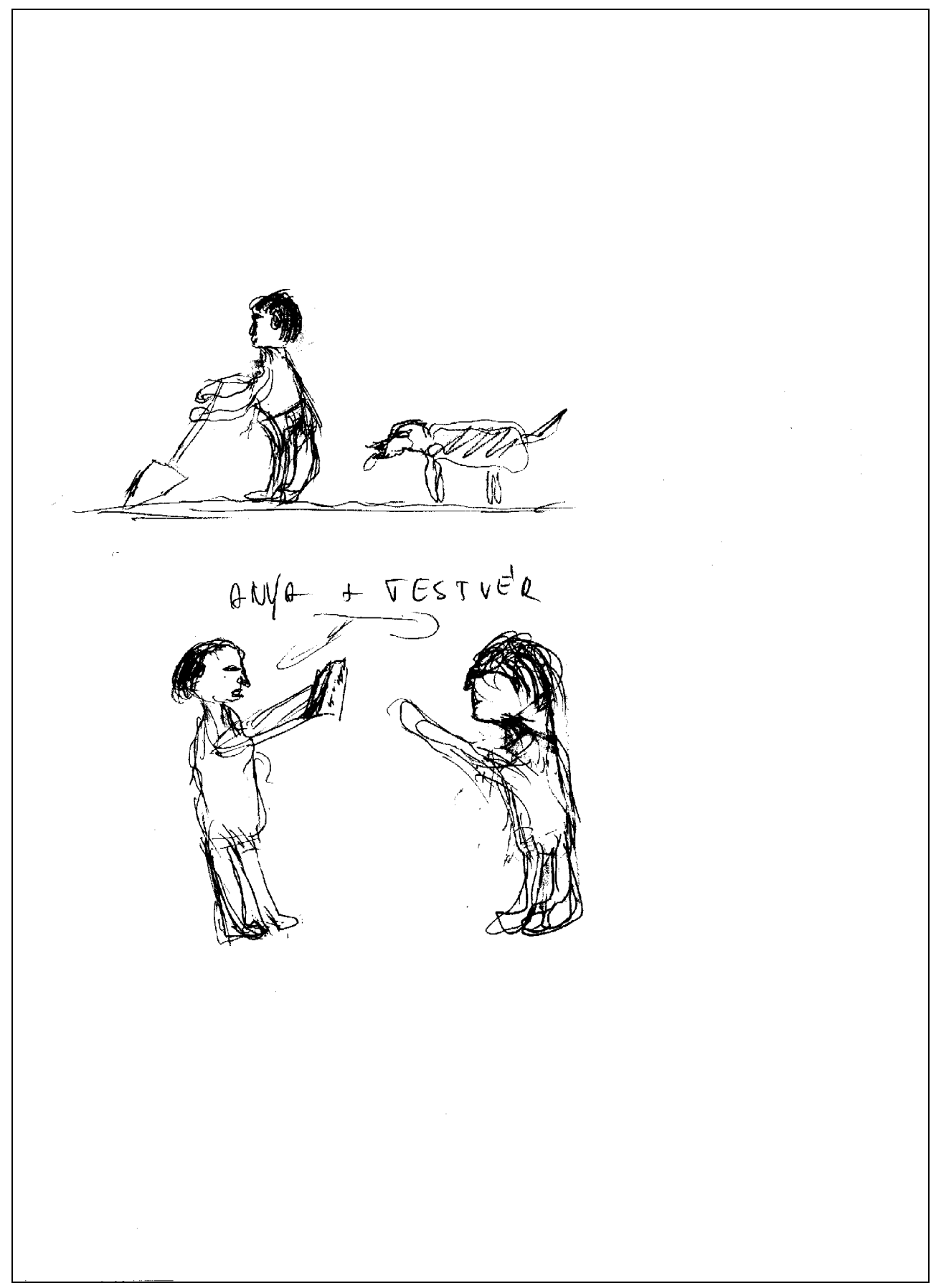

6. ábra. Aláhúzott figurák 
Az összes alak marginális ábrázolása, ha a lap egyetlen szélén találhatóak, a közös dolgokból való kivonulást, elhúzódást, illetve érzelmi beszúkülést vagy függőséget jeleznek (előfordulhat azonban alacsony IQ vagy mozgáskoordinációs problémák esetén is). Amikor a gyermek a lap hátoldalára rajzol valakit, akkor (többnyire indirekt) konfliktust gyaníthatunk a személlyel való kapcsolatban; ugyanez a saját alaknál visszahúzódó, a család által elutasított gyermekeknél fordul elő. Az elutasítás egy finomabb, latens, de hasonló jelentésű formája, ha sokáig csak bámul a lapra a személy, és nem rajzol.

$\mathrm{Az}$ „X-szindróma” (7. ábra) egy rajzolt tárgyban markánsan megjelenő, hangsúlyozott (azaz árnyékolt vagy megerősített) kereszteződő vonalakat jelenti, amikor a tárgy valakihez kapcsolódik a rajzban (például a vasalódeszka lábai, amely az anyához tartozik). Jelentése az erők-ellenerők konfliktusa, az erős felettes én, a fokozott tudatosság igénye. Gyakran azokat a személyeket jelöli a gyermek a rajzon, akikkel erősen ambivalens.

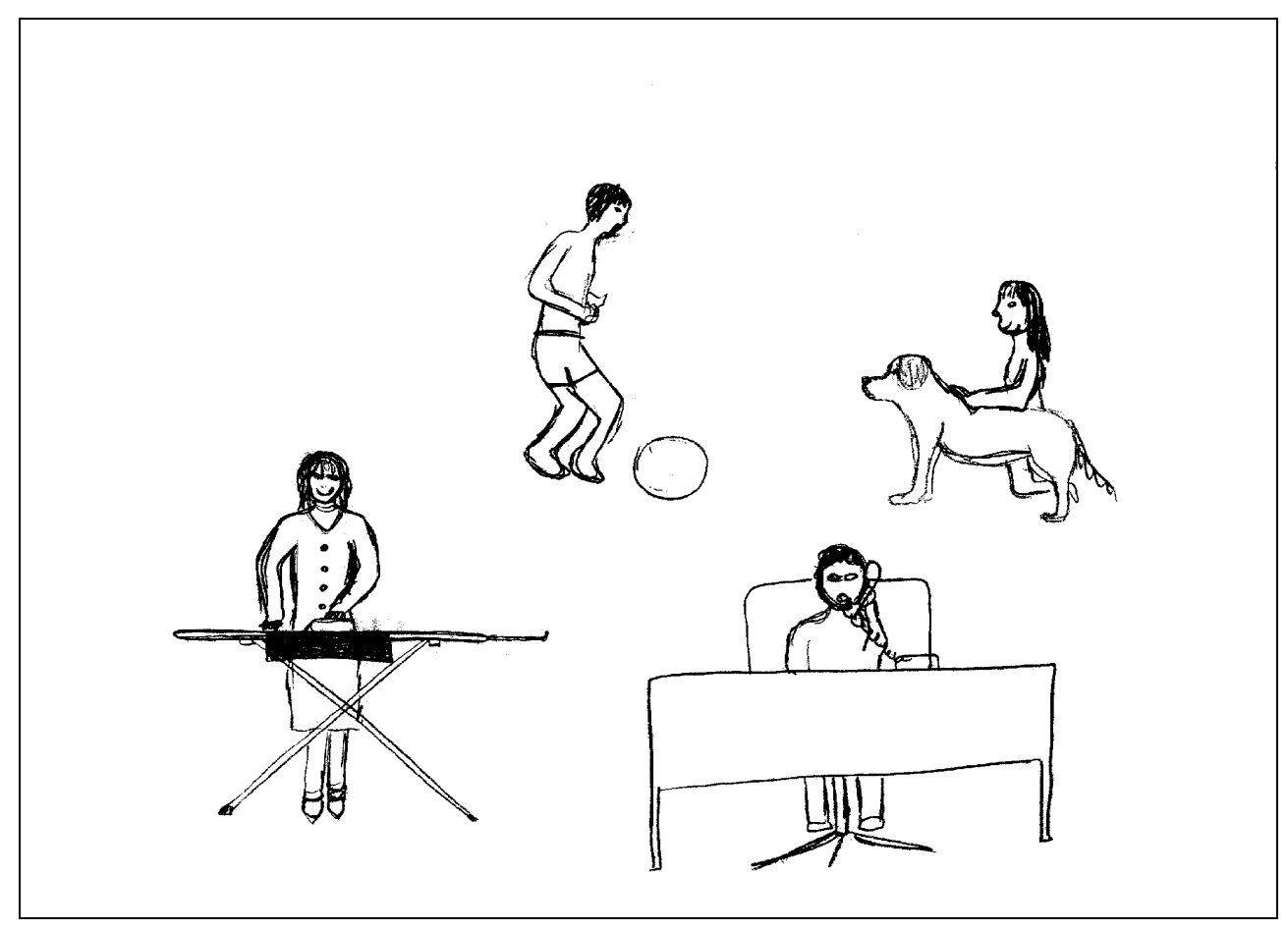

7. ábra. Az „X-szindróma”

Ha a gyermek elkezd valamit rajzolni, majd abbahagyja a megkezdett rajzot és egy másikat rajzol meg helyette, ezzel esetenként az első rajz tartalmától vagy dinamikájától való nagyfokú félelmét árulhatja el (az eredeti helyett egy pszichológiailag biztonságosabb rajzot készít). 


\section{A KINETIKUS ÁLLATCSALÁD}

A kinetikus állatcsalád (Animal Kinetic Family Drawing, AKFD) rajzát JONES (1985) javasolta abból a meggondolásból, hogy az állatok a tudattalan impulzusok, projekciók szimbólumai, és tükrözik a gyermek valódi, tudattalan érzéseit saját családjáról. A szerző szerint a kinetikus állatcsalád indirektebb, semlegesebb téma a kinetikus családrajznál, ezért kevésbé mozgósítja az elhárító mechanizmusokat. Az állat gyakori motívum a gyermekek más projektív válaszaiban is (szabadrajzban, Rorschach-tesztben stb.).

A módszerről kevés szakirodalmi adat van, az állatrajzokról és az állatcsalád értelmezéséről azonban sok tanulmányt találunk (SCHWARTZ, ROSENBERG, 1955; BrEm-Gräser, 1957; Kos, BIERMAN, 1973; AvÉ-LaLlemant, 1976; GMElin, 1978; HÁRDI, 1991). Saját gyakorlatunkban azonban igen hasznosnak találtuk a technikát, ezért röviden (az általános állatszimbolika ismertetése nélkül) bemutatjuk. Az instrukció a következő: „Rajzolj egy állatcsaládot úgy, hogy minden állat csináljon valamit. Rajzolj egész állatokat. Tehát minden állat csináljon valamit - végezzen valamilyen cselekvést.” („Draw a picture of a family of animals, doing something. Try to draw whole animals, not cartoons or stick animals. Remember, make every animal doing something-some kind of action”, 189.) A rajz elkészülte után meg kell kérdezni, kik alkotják az állatcsalád tagjait, hány évesek, és azt, hogy ha a gyermek egy állatgyerek volna a rajzon, akkor melyik állat lenne.

JONES (1985) 6-10 éves gyermekek (elvált szülők gyermekei vs. teljes családban éló gyermek) KFD és AKFD rajzait hasonlította össze. Kis elemszámú mintáján $(\mathrm{n}=38)$ statisztikai különbségeket nem talált, azonban számos, klinikailag releváns egyedi mintázatot azonosított. Érdekes például, hogy míg az elvált szülók gyermekeinek 40\%-a rajzolt különböző állatfajokat a kinetikus állatcsaládrajzban, ugyanez az arány a kontrollcsoportban csak $5 \%$ volt. Az eltérő fajú állatok kombinálása a gyermeknek azt az érzését fejezheti ki, hogy a család nem egységes, nem tartozik össze.

\section{A KINETIKUS CSALÁD- ÉS ÁLLATCSALÁDRAJZ KLINIKAI ALKALMAZÁSÁNAK ILLUSZTRÁCIÓJA}

Az alábbiakban röviden ismertetünk egy esetet, amely bemutatja a kinetikus családrajz és a kinetikus állatcsaládrajz klinikai alkalmazását.

Tamás 12 éves és 7 hónapos, az általános iskola 6. osztályát végzi. Megjelenését gyermekpszichológiai rendelésen az osztályfönök kérte viselkedési problémák miatt. A szülók is úgy látják, hogy Tamás az osztályban „a legrosszabbak közé tartozik”, de az iskolát okolják emiatt, és iskolaváltoztatáson gondolkoznak. Az iskolai viselkedési problémáknál fontosabbnak látják azt, hogy Tamás nem akar tanulni otthon, csak „számítógépezik” és képregényeket olvas; a szülők nem tudják, hogyan vehetnék rá a tanulásra. Nagyon elfoglalt, aktív életet élnek, Tamás édesanyja menedzser, édesapja több munkahelyen is dolgozik. Tamásnak egy testvére van, a néhány évvel fiatalabb öcs, aki nagyon jól tanul, emellett a sportban is eredményes. 
Tamás a pszichológiai vizsgálat során hagyományos családrajzot, kinetikus családrajzot és kinetikus állatcsaládot is rajzolt. A projektív rajzvizsgálat kevéssé strukturált helyzetében biztosan tájékozódott, nem fejezte ki igényét irányításra, sem pedig kételkedését képességeiben. A rajzokat élvezettel, a cselekvésbe involváltan készítette, a feladatra összpontosított (ami feladattudatot, koncentrációs készséget mutat). Grafikus sémarepertoárja gazdag (grafémáinak differenciáltsága $^{5}$ absztrakciós képességet, a kognitív sémák differenciáltságát feltételezi), rajzai sablonoktól mentesek, individuálisak (jó projekciós, elaborációs készség). Gondosan rajzolt, igyekezett jó teljesítményt nyújtani (teljesítménymotiváció), amit rövid gondolkozás után, gyorsan és határozottan, javítgatások nélkül meg is valósított (magas igényszinthez magas teljesítményszint társul).

A családrajzban (8. ábra) a terapeuta a szabad projekció miatt nem a saját család rajzát, hanem egy általános családot kért („Rajzolj egy családot”). A család mégis olyan négytagú, nukleáris család lett, amely Tamás saját családját reprezentálja. Harmonikus, egységes, globálisan pozitív családot ábrázol, ahol számos ked-

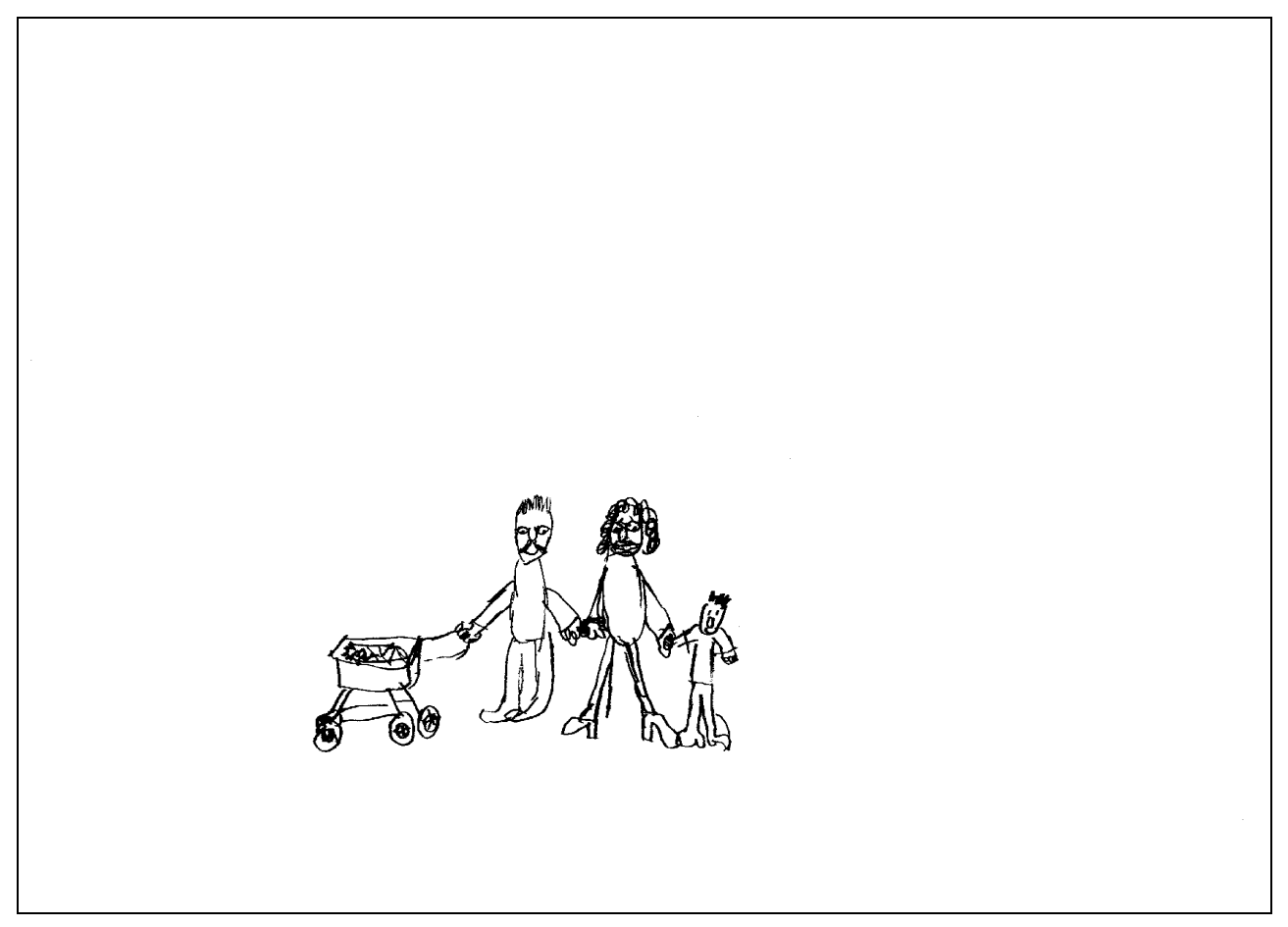

8. ábra. Tamás családrajza

5 A grafémák differenciáltsága nem azonos a rajz tagoltságával, melybe nemcsak a grafémák komplexitása, de azok formai változatossága és az ábrázolás szándékához illeszkedésük is beletartozik (vö. SEHRINGER idézett munkáival). 
vező jelzést találunk: testi kontaktust (egymás kezét fogó családtagok), kis téri távolságokat a családtagok között (egyetlen csoportot képeznek), szoros anya-gyerek kapcsolatot (Tamás az édesanya kezét fogja), arányos méretviszonyokat. A rajzon a legérdekesebb a testvér transzformációja pólyába burkolt kisbabává és az apa felemelése (függőleges eltolás a lapon felfelé). Alacsony önértékelésre utalnak azonban a szokásosnál kisebb méretű alakok, a rajzi szukcesszió (önmagát rajzolja utoljára) és a saját alak bizonytalan testtartása: Tamás belekapaszkodik édesanyja kezébe, aki szétvetett lábbal, magas cipőben, barátságtalan arccal áll. Az apa a testvérrel foglalkozik.

A kinetikus családrajzon (9. ábra) Tamás először magát rajzolta le (,,Kosárlabdázok, a büntetöról rádobom a labdát”), majd az anyát (,Anyukám, biciklizik”), ezután az apát („Apu, rárúgja a labdát a kapura”), végül a testvért („Kistestvérem, kapusként véd"). A rajzról alkotott első benyomás egy mozgalmas, aktív, ugyanakkor szétszórt család, ahol az apa a testvérrel foglalkozik, az anya mindenki mástól különálló tevékenységet végez, Tamás pedig magányosan játszik egy csapatjátékot, kifelé dőlve a családból. Az anya és Tamás fizikai távolsága ambivalens: szorosan egymás mellett vannak ugyan, mégis hátat fordítanak egymásnak, és a bicikli kereke Tamás lábát nyomja. Az anya méretében is, formailag is kislányszerü, a kerékpárral a testvér-apa diád felé halad. Tamás idealizálva, széles vállakkal, erősnek, nagynak

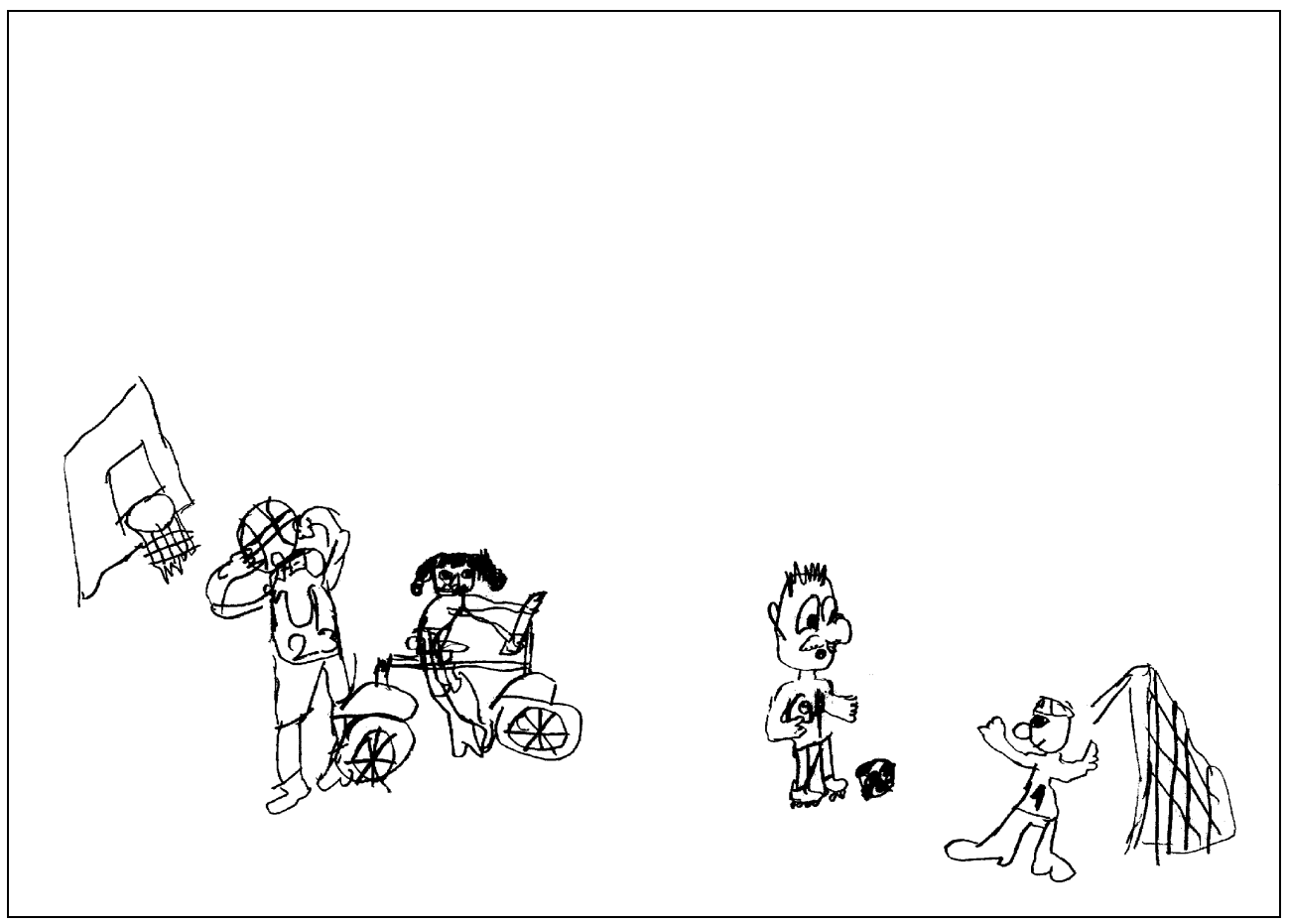

9. ábra. Tamás kinetikus családrajza 
rajzolta meg magát. A nagy méret valószínűleg kompenzatórikus ego-dilatációval jött létre, amelyet a rajz algoritmusokkal ${ }^{6}$ végzett, közvetlen grafikus elemzésének (VASs, 1997, 1998a, 1999b, 2000a) adatai is alátámasztanak: az egyes figurák négyzetes területe a saját alaknál a legnagyobb. Tamás távol áll az apától, tevékenységében mégis vele azonosul (mindketten labdával játszanak és számmal jelölt sportmezt viselnek). Arca zavarosan ábrázolt, arckifejezése felismerhetetlen. A család legkarakteresebb figurája az apa; felülről néz lefelé a testvérre, aki szétvetett lábbal-kézzel, mosolyogva véd(ekezik). Az anya nem törődik Tamással, szeretet nem érződik köztük. A gyermek rajzhoz füzött, szóbeli megjegyzéseiben „megüti” a terapeuta fülét a „büntető” kifejezés, és az a kifejezés, hogy az apa „rárúgja” a labdát a kapura (a rajz szerint a testvérre). Interakció csak az apa-testvér diád között jelenik meg.

A kinetikus családrajz hipotézisei szerint a labdázás lehet a rivalizáció kifejeződése. Rivalizációt az apa-testvér diádban látunk (ahol az apa generálja), valamint Tamásnál, de nála gátolt formában (felfelé irányított, fejre rajzolt labda). Tamás nem vesz részt abban, amit az apa és a testvér csinál (féltékenység). Tamás arctalansága és a magas aktivitási szintünek ábrázolt apa Tamás alacsony önértékelését jelzi.

Az emberábrázolást véve figyelembe, az apa hegyes ujjai, a sportcipő tüskéi és a hegyesen égnek álló haj az apa autoriter agressziójáról tanúskodnak. A saját alak és az anya között lévő fizikai akadály (bicikli) kettejük pszichológiai távolságát jelzi. Tamás önmagát az apánál is nagyobbnak rajzolja (fenyegetett én, túlkompenzáció), és feljebb kerül a papíron, mint a testvér (dominálni akar felette; a saját alak algoritmusokkal mért súlypontja kétszer olyan magasan található a lapon, mint a testvéré). Közel rajzolja magát az anyához, távol az apától, amivel az anyától várt figyelem és elfogadás igényét ábrázolja; a távolság az apától ezzel szemben az érzelmi elszigeteltség, elutasítottság érzéseit jeleníti meg. Tamás elfordulása a családtól kifejezheti azt is, hogy kamaszodik és keresi a saját útját.

A kinetikus állatcsaládrajzhoz (10. ábra) Tamás a következőket füzi hozzá: „A nyuszi és a teknös versenyt fut, a róka, a kenguru és a kenguru kisbabája sakkozik”, „a pók tarzanozik (= lóg, himbálózik a kötélen), a krokodil és a cápa pedig fogócskázik, ók testvérek, mellettük az aljnövényzet". Tamás legszívesebben a nagy kenguru lenne, mert az „nagyot tud ugrani, és csoportokban él,... ha egy nagy vad, egy húsevő meg akarna enni, akkor elüznénk csoportszellemmel”. Asszociációiban a pók félelmet hordozó állat (,,iszonyat”, mondja), a kiskenguru pedig ,maflácska, zöldfülü, nem szokott hozzá az új életéhez, kiközösitik a nagy állatok, például az elefánt".

A rajz izolált csoportokat, páros interakciókat, azaz széttagolódó családot mutat be, ahol a központi motívum a versengő rivalizálás (versenyfutás, fogócska, sakkozás; a kenguru nagyot tud ugrani). Ugyanehhez a képzetkörhöz tartozik a tulajdonságok hasítása, polarizálása (a nyúl gyors, a teknős lassú). Az állatválasztások

\footnotetext{
${ }^{6}$ Az algoritmusos elemzés a szkennerrel számítógépbe olvasott rajz objektív elemzését jelenti, melyben egy számítógépprogram ismeri fel és méri meg a rajz meghatározott formai-szerkezeti jellemzőit (például méretviszonyok, téri pozíció, szimmetria, árnyékolás és részletezés mennyisége stb.). A szerző doktori disszertációjának keretében kidolgozott módszer részletes ismertetése megtalálható a szerző már idézett munkáiban.
} 


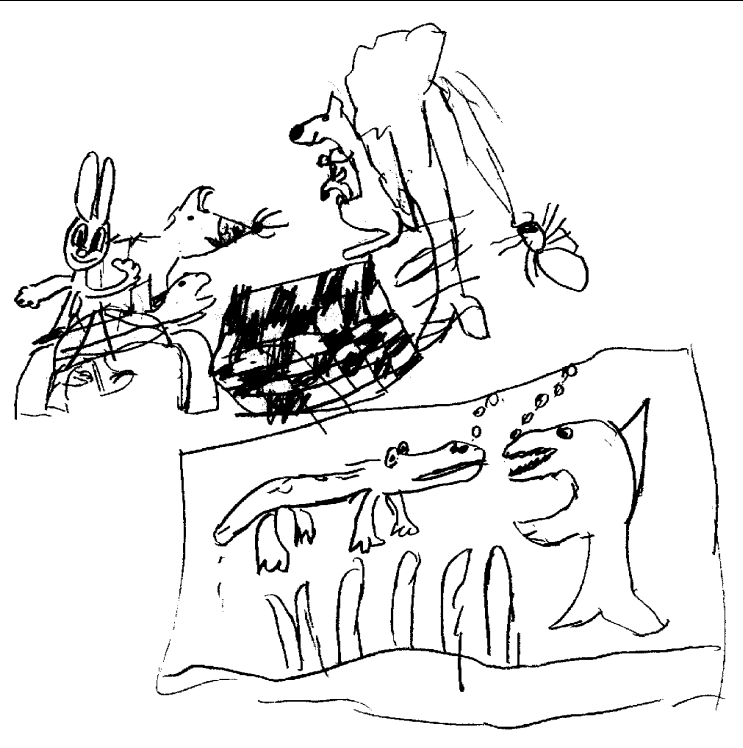

10. ábra. Tamás kinetikus állatcsaládrajza

ban általában a félelem és az agresszió dominál (pók, róka, krokodil, cápa nagy fogakkal). A krokodil mint a testvérállatok egyike krónikus testvérféltékenységet jelez (GMELIN, 1978). A nyúl a családrajz-irodalomban a szorongást generáló családi szituációt; a pók a "gonosz", illetve a férfias karakterü, szorongást kiváltó anyát (KOS, BIERMANN, 1973), a problematikus anya-gyerek kapcsolatot és a testvérkonfliktust szimbolizálja. A nagy kenguru hasában megbújó kiskenguru a duálunió archaikus vágyát fejezi ki (a gyermeket megvédő anya utáni vágy, együtt a szorongás jelzésével: GMELIN, 1978). A ragadozó testvérállatok enkapszulációval izoláltak: vágyaiban azonosul a sikeres testvérrel, kettejük rivális kapcsolatába sok pszichés energiát, libidót invesztál. A rajz sok mozgásos elemet tartalmaz: nyugtalanság, késztetés mozgásos aktivitásra a belső feszültség levezetéséhez, ami abban a fokozódó impulzivitásban is megnyilvánul, amelyet a sakktábla kockáinak szabálytalanságában (és általában a rajz düledező, görbe formáiban, aszimmetriájában, valamint a tág határok közt fluktuáló nyomáserősségben) látunk. A félelmetes pók hálója, amely a fa köré tekeredik, a megkötözöttséget, a tehetetlenségérzést fejezheti ki (a motívum felbukkan már az első családrajzban, a „gúzsba kötött” pólyás babában), a túl erôs, utolérhetetlen apától való szorongás miatt. Erre utalnak a szorongást keltő állatok, a nagy vad, a húsevő, amely meg akarja enni, valamint az asszociációkban szereplő elefánt, aki kiközösíti a maflácska kiskengurut. 
Összesítve a három rajzot, a következő mintázatokat ismerhetjük fel: a család széttagolódása három részre (anya-Tamás-az apa és a testvér diádja); frusztrált rivalizálás az apával és a testvérrel, testvérféltékenység; a jó képességek ellenére alacsony önértékelés; frusztrált kötődés az anyához, a szorosabb kötelék vágyával; az apa Tamás fantáziáiban büntető, fenyegetô karaktert hordoz; az általa okozott szorongás ellen Tamás azonosulással védekezik.

A rajzokból kibontakozó klinikai képet a családi anamnézisen kívül egy korábbi logopédiai-pszichológiai szakvélemény és Tamás metamorfózis-tesztje is megerősíti. Tamás szorongását mutatja, hogy Tamás az anya kezét fogva alszik el minden este, éjszakánként átmegy a szülőkhöz aludni, és szorong attól, hogy betörnek hozzájuk. A szakvélemény Tamást kiemelkedő logikus gondolkodással rendelkező, testvérével már az óvodai csoportban is rivalizáló, negatív énképe miatt alacsony beszédkésztetésủ gyermeknek írja le. A metamorfózis-teszt alacsony önértékelést, szorongást, a nárcisztikus tükrözés igényét, teljesítménycentrikus attitűdöt és koraéretten internalizált, irreális, ezért frusztráló felnőtt értékeket mutat.

\section{A KINETIKUS CSALÁDRAJZ ÉRTÉKELÉSE}

A kinetikus családrajzról hazai normatív adatok nem jelentek meg, ${ }^{7}$ támpontul egyelőre BURNS és KAUFMAN (1972) klinikai mintájának adatait használhatjuk. Az amerikai normatív adatok egyik érdekessége, hogy az apa leggyakoribb cselekvései az olvasás, a tévénézés és a munka (5-8\%); az anya általában főz, mosogat, vasal vagy porszívózik (5-16\%); a saját alak pedig játszik, eszik, sétál, lovagol, illetve tévét néz (5-13\%). A fiúk és lányok nem különböznek lényegesen az ábrázolt cselekvések gyakoriságában.

A kinetikus családrajzról objektív skálák is rendelkezésre állnak. Ezek közé tartozik O'BRIEN és PATTON (1974) értékelési rendszere, melyben külön pontozza a cselekvéseket, az emberrajz jellemzőit, az elhelyezést, a távolságokat és az interakciós akadályokat. Eredményeik szerint a manifeszt szorongást legjobban az apa aktivitási szintje jelzi előre (minél erősebb és aktívabb az apa, annál nagyobb a gyermek szorongása). Az énfogalom (self-concept) pozitivitását ugyancsak az apa aktivitási szintje (fordított arányossággal) mutatja a legmegbízhatóbban; a szociális énfogalom pozitivitása a saját alak felé forduló apával mutat szoros kapcsolatot.

WRIGHT és MCINTYRE (1982) felnőttek vizsgálatára dolgoztak ki olyan depresszióskálát (Family Drawing Depression Scale, FDDS), amely a kinetikus családrajzban értékeli a depressziós rajzi jellegzetességeket. A felnőtt depressziós betegek gyakran kihagyják magukat a családrajzból. Ha megrajzolják önmagukat, akkor kisebbnek ábrázolják a saját alakot más személyeknél, fizikailag távol kerül-

\footnotetext{
7 A szerzó a Research Support Scheme „Computer assisted analysis of the projective assessment of family structure and relations" címü, kétéves projektjének (No. 1427/1998) keretében vizsgálja egy nagyobb, hazai klinikai populáción a kinetikus családrajz alkalmazásának lehetőségét. A kutatás eredményei várhatóan 2000-2001-ben kerülnek közlésre.
} 
nek a papírlapon a családtagoktól, és nem állnak velük interakcióban, például vonalakkal, tárgyakkal szigetelik el magukat. Nemcsak a saját alak, de a család egésze is kevés interakciót ábrázol. A saját alak és a család egésze külön-külön is kevés mozgást, energiát mutat; a saját alakon nem ismerhető fel érdeklődés a környezet iránt (például sport, hobbi, természet nem jelenik meg a képen). Sok üres tér marad szabadon a lapon, és reménytelenség érződik a kép egészéből. Az FDDS klinikai hasznosságát megerősíti PEEK és SAWYER (1988) vizsgálata is, akik krónikus fájdalom-szimdrómában szenvedő betegek közül a skála alkalmazásával ki tudták választani a depressziós személyeket.

Fontos megemlíteni THARINGER és STARK (1990) vizsgálatát, akik egy 37 itemből álló pontrendszert hasonlítottak össze egy négyitemes, globális-holisztikus értékelési rendszerrel. A globális változók a következők voltak: a családtagok hozzáférhetetlensége egymás számára; a családtagok elfoglaltsága; a rajz mögött álló kedvezőtlen családstruktúra és a családtagok figuráinak emberszerűsége (a grafikus megjelenítés módja). A szerzők szerint a négy item úgy válik értelmezhetővé, ha belehelyezzük magunkat a rajzba, lehetőleg a gyermek pozíciójában. A tanulmány azért figyelemre méltó, mert az aprólékos kódolási leírást intuitív, globális definícióval helyettesítő módszer sokkal jobban különbséget tett a vizsgált csoportok között, mint a 37 itemes skála (a globális elemzésről lásd VASS, 1996b; VÁRFINÉ KOMLÓsı és munkatársai, 1996).

A kinetikus családrajz reliabilitására és validitására ugyanaz érvényes, mint a rajzvizsgálatokra általában: az elégtelen kódrendszerrel végzett vizsgálatok, az egyetlen változót alkalmazó vagy az alapvető moderátorváltozókat (életkor, nem, SES, IQ stb.) figyelmen kívül hagyó tanulmányok alacsony teszt-reteszt, illetve interrater reliabilitást, továbbá alacsony konstruktvaliditást mutatnak (MARTIN, 1955; MCPHEe, WEgNer, 1976). A többváltozós elemzéssel elvégzett vizsgálatok eredményei (például SIMS, 1974; COOK, 1991) ezzel szemben klinikailag is hasznosítható, markáns eredményekről számolnak be. Ugyancsak fontos a globálisholisztikus elemzés, amelynek kiváló, módszertanilag is követendő példája THARINGER és STARK (1990) említett vizsgálata.

A kinetikus családrajz alapvetően kétféleképpen használható. Ha pszichometriai értelemben vett teszt helyett hipotézisgeneráló eszköznek fogjuk fel, akkor szerepe a klinikus számára olyan pszichodiagnosztikai hipotézisek megalkotása, melyek további igazolást kívánnak. Ha szigorú értelemben vett tesztként akarjuk használni (amelyre egyébként a módszer ígéretes perspektívákat kínál), akkor viszont az életkort és más fontos moderátorváltozókat figyelembe vevő normákra van szükség (például milyen életkorban mi a leggyakoribb rajzolási sorrend, milyen méretűek fiúknál-lányoknál az egyes szülők stb.), továbbá jól megtervezett reliabilitás-, illetve validitásvizsgálatokra. Ez utóbbiak legfontosabb alapelvei az objektív, reprodukálható értékelési rendszer használata, a globális-holisztikus elemzés, valamint az egyedi grafikus jegyek helyett a komplex mintázatok feltérképezése olyan többváltozós statisztikai eljárásokkal, mint a clusteranalízis, a lépésenkénti diszkriminanciaanalízis (VASs, 1998b, 1999a), a többszörös regresszióanalízis vagy a többdimenziós skálázás (BROWN és munkatársai, 1987). 
Összegzésképpen megállapíthatjuk, hogy a kinetikus családrajz megítélése kedvezô a projektív pszichodiagnosztikában (lásd például FALK 1981-es kritikai tanulmányát). A nemzetközi szakirodalomban megjelent publikációk száma alapján a kinetikus családrajz a leggyakrabban alkalmazott családrajzmódszer (KNOFF, ProuT, 1985), amelyet előszeretettel alkalmaznak nem csak a klinikumban, de empirikus vizsgálatokban is. Megítélését az nehezíti, hogy - mint a projektív rajzoknál általában - sok empirikus tanulmány módszertanilag egyszerúen alkalmatlan valódi következtetések levonására (a módszertanról lásd HAMMER, 1969; KNOFF, Prout, 1985; HANDLER, HABENICHT, 1994; VASs, 1996b, 1998c, 2000d).

A projektív módszerek vizsgálatához megfelelő módszertant alkalmazó vizsgálatok eredményei azonban ígéretesek, és igazolni látszanak L. B. Amesnek, a Projektív Módszerek Társasága (Society for Projective Techniques) elnökének 1972-es véleményét, aki a kinetikus családrajzot jelentőségében a Rorschach-teszt mellé állítja, és a „projektív technikák égboltján ritkán feltűnő, fényes csillagok” (V. oldal) egyikének tartja. Saját tapasztalataink egybecsengenek Ames lelkes szavaival, melyet e tanulmány befejezéseként egy kissé bővebben is idézünk:

„Bárki, aki a KFD tesztet használja, élvezettel tapasztalhatja azt az izgalmat, hogy az emberi viselkedés mérésének egy bámulatosan hatékony, új módszere kezdeteinél lehet jelen. Az eljövendő évek sokat ígérnek ennek az új módszernek. A KFD valódi hozzájárulást nyújthat minden klinikus projektív eszköztárához. Véleményem szerint e tesztnek nagy jövője lesz mindazoknál a szakembereknél, akik munkájukban fontosnak tartják a gyermekrajzok megértését és értelmezését - a gyermekrajzoknak, melyek olyan sokat mondhatnak és mondanak nekünk arról, hogy milyenek a gyermekek, melyek a problémáik és milyennek látják az életet.” (BURNS, KAUFMAN, 1972, Bevezetés, VIII.)

\section{IRODALOM}

ABEGG, W. (1973) Der Familientest. Werner Classen, Zürich

Aвraнam, A. (1991) The inner group: its manifestation in drawings and in the actual group. Group, 15, 28-38.

Ames, L. B. (1972) Introduction. In Burns, R. C., Kaufman, S. H. Actions, Styles and Symbols in Kinetic Family Drawings $(K-F-D)$ : An Interpretative Manual. V-VIII. Brunner/Mazer, New York

AvÉ-Lallemant, U. (1976) Kinder zeichnen ihre Eltern: Erlebnis und Ausdruck in Tierbildern. Walter, Olten

Biermann, G. (1962) Die Familien-Neurose in ihrer Projektion im Familien-Zeichentest. Psyche, 16, 127-141.

BORELli-VinCENT, M. (1965) L'expression des conflits dans le dessin de la famille. Revue de Neurospychiatrie Infantile, 13, 45-65.

Brem-GräSer, L. (1957) Familie in Tieren. Ernst Reinhardt, München/Basel 
Brown, J. M., Henderson, J., Armstrong, M. P. (1987) Children's perceptions of nuclear power stations as revealed through their drawings. Journal of Environmental Psychology, 7, 189-199.

Burns, R. C. (1982) Self-Growth in Families: Kinetic Family Drawings (K-F-D). Brunner \& Mazel, New York

Burns, R. C., Kaufman, S. H. (1970) Kinetic Family Drawings (K-F-D). An Introduction to Understanding Children through Kinetic Drawings. Brunner \& Mazel, New York

Burns, R. C., Kaufman, S. H. (1972) Actions, Styles and Symbols in Kinetic Family Drawings (K-F-D): An Interpretative Manual. Brunner \& Mazel, New York

Cook, K. M. (1991) Integrating Kinetic Family Drawing into Adlerian Life-Style interviews. Individual Psychology, 47, 521-526.

Corman, L. (1964) Le test du dessin de famille dans la pratique médico-pédagogique. P.U.F., Paris

Corman, L. (1965) Le test du dessin de famille. Revue de Neuropsychiatrie infantile, 13, 67-80.

Croco, L., Suziot, M. (1968) Une dimension profonde dans l'analyse du dessin de la famille chez l'enfant: le schéma corporel. Encéphale, 57, 34-39.

FALK, J. D. (1981) Understanding children's art: An analysis of the literature. Journal of Personality Assessment, 45, 465-473.

Feuer, M. (1992) „Elrontott” családrajzok szerepe a gyermek-pszichodiagnosztikában. In Feuer M., Popper P. (szerk.) Gyerekek, szülök, pszichológusok. (Pszichológiai mühely 9.) 95115. Akadémiai Kiadó, Budapest

GiLlesPIE, J. (1989) Object relations as observed in projective Mother-and-Child drawings. The Arts in Psychotherapy, 16, 163-170.

Gmelin, O. F. (1978) Mama ist ein Elefant. Deutsche Verlags-Anstalt, Stuttgart

Goodenough, F. L. (1926) Measurement of Intelligence by Drawings. Harcourt, Brace and World, New York

HALÁsz A. (1993) A családrajz jelentősége a gyermekterápiában. In A gyermek-pszichoterápia elmélete és gyakorlata III. 2-1642. Nemzeti Tankönyvkiadó, Budapest

HAmmer, E. F. (1969) Draw-a-Person: Back against the wall? Journal of Consulting and Clinical Psychology, 33, 151-156.

Handler, L., Habenicht, D. (1994) The Kinetic Family Drawing Technique: A review of the literature. Journal of Personality Assessment, 62, 440-464.

HÁRDI I. (1983) A dinamikus rajzvizsgálat. Medicina Könyvkiadó, Budapest

HÁRDI I. (1991) Dinamikus állatrajzvizsgálat. Psychiatria Hungarica, 6, 279-290.

Hárdi I., Adorjáni F., Hajnal Á., Moussong-Kovács E., TÉnyi T., Trixler M., Vass Z. (2000) A képi kifejeződés és müvészeti terápia jelene és perspektívái - az ezredfordulón. Magyar Pszichiátriai Társaság VIII. Vándorgyúlése, Györ, 2000. január 26-29. Abstracts p. 106.

HÁrdi, I., SAÁGHY, M. (1982) The Problem of the Stick-Figure. In Andreoli, V. (ed.) The Pathology of Non-verbal Communication. 239-244. Masson, Milano

HARSÁNYI I. (1968) Iskolások családrajza mint a családi relációk és az önértékelés feltárásának eszköze. Pszichológiai Tanulmányok VIII. 171-195. Akadémiai Kiadó, Budapest

Hulse, W. C. (1951) The emotionally disturbed child draws his family. Quarterly Journal of Child Behavior, 3, 152-174.

Hulse, W. C. (1952) Childhood conflicts expressed through family drawings. Journal of Projective Techniques, 16, 66-79. 
Jones, R. M. N. (1985) Comparative study of the Kinetic Family Drawing and the Animal Kinetic Family Drawing in regard to self-concept assessment in children of divorced and intact families. The Arts in Psychotherapy, 12, 187-196.

KAISER, D. H. (1996) Indications of attachment security in a drawing task. The Arts in Psychotherapy, 23, 333-340.

Knoff, H. M., Prout, H. T. (1985) The Kinetic Drawing System: A review and integration of the Kinetic Family and School Drawing techniques. Psychology in the Schools, 22, 5059.

Knoff, H. M., Prout, H. T. (1993) Kinetic Drawing System for Family and School: A Handbook. Western Psychological Services, Los Angeles

Kos, M., Bierman, G. (1973) Die verzauberte Familie. Ernst Reinhardt, München/Basel

Machover, K. (1949) Personality Projection in the Drawing of the Human Figure. Thomas, Springfield

MARTIN, W. E. (1955) Identifying the insecure child: III. The use of children's drawings. The Journal of Genetic Psychology, 86, 327-338.

McPhee, J. P., Wegner, K. (1976) Kinetic-Family-Drawing styles and emotionally disturbed childhood behavior. Journal of Personality Assessment, 40, 487-491.

O'Brien, R., Patton, W.F. (1974) Development of an objective scoring method for the Kinetic Family Drawing. Journal of Personality Assessment, 38, 156-164.

Peek, L., SAwyer, J. P. (1988) Utilization of the Family Drawing Depression Scale with pain patients. The Arts in Psychotherapy, 15, 207-210.

Porot, M. (1965) Le dessin de la famille. Revue de Psychologie Appliquée, 15, 179-192.

Prout, H. T., Phillips, P. D. (1974) A clinical note: The Kinetic School Drawing. Psychology in the Schools, 11, 303-306.

SCHETTy, S. A. (1974) Kinderzeichnungen: Eine Entwicklungspsychologische Untersuchung. (Diss., Universität Zürich.) Juris, Zürich

SChwartz, A. A., Rosenberg, I. H. (1955) Observations on the significance of animal drawings. American Journal of Orthopsychiatry, 25, 729-746.

SEHRINGER, W. (1983) Zeichnen und Spielen als Instrumente der psychologischen Diagnostik. Schindele, Heidelberg

SEHRinger, W. (1989) Systemanalyse von Kinderzeichnungen. Zeitschrift für Menschenkunde, 53, 2-21., 80-91.

SEHRINGER, W. (1999) Zeichnen und Malen als Instrumente der psychologischen Diagnostik. Schindele, Heidelberg

SheArn, CH. R., Russell, K. R. (1969) Use of the family drawing as a technique for studying parent-child interaction. Journal of Projective Techniques, 33, 35-44.

Sims, C. A. (1974) Kinetic Family Drawings and the Family Relations Indicator. Journal of Clinical Psychology, 30, 87-88.

Tharinger, D., StARK, K. (1990) A qualitative versus quantitative approach to evaluating the Draw-A-Person and Kinetic Family Drawing: A study of mood- and anxietydisorder children. Psychological Assessment: Journal of Consulting and Clinical Psychology, 2, $365-375$. 
VÁrfiné Komlósi A., VAss Z., RózSA S. (1996) A depresszióra való hajlam serdülókori felismerésének és módosításának lehetőségei. Magyar Pszichológiai Szemle, LII, 101-124.

VASs Z. (1996a). Projektíu kérdések a ház-fa-ember teszthez. Oktatási segédanyag, kézirat (URL http://www.psyche.elte.hu/ vasszolt)

VASs Z. (1996b). A projektív rajzok előnyei, problémái és kutatási távlatai. Magyar Pszichológiai Szemle, LII, 1-3, 81-100.

VAss, Z. (1997) A Computerized Psychometric Approach to Projective Drawings. XVth Congress of the International Society of Art and Psychopathology, Biarritz, France, October 8-12. Abstracts p. 33.

VAss, Z. (1998a) PsychMet for Windows version 2.0. Program for Psychometric Analysis of Projective Drawings (program). Eötvös Loránd University, Budapest

VAss, Z. (1998b) The inner formal structure of the H-T-P drawings: an exploratory study. Journal of Clinical Psychology, 54, 1-9.

VAss, Z. (1998c) A rajzvizsgálat módszertani problémái. Magyar Pszichiátriai Társaság IV. Nemzeti Kongresszusa, Budapest, 1998. január 28-31., Abstracts p. 44.

VASs, Z. (1999a) A projektív rajzvizsgálat objektivizálása felé: elemzés algoritmusokkal (Szkizofrén betegek farajzainak térszerkezeti elemzése). Pszichológia (Publikációs díj), 19, 79-124.

VASs, Z. (1999b) La nouvelle perspective de l'examen des dessins projectifs: l'analyse psychométrique avec algorithmes. La Revue Française de Psychiatrie et de Psychologie Médicale, 31, 94-97.

VAss Z. (1999c) Projektív rajzvizsgálat algoritmusokkal (A számítógépes formai elemzés módszerének bemutatása a szkizofrénia képi kifejeződésének tükrében). $P h . D$. disszertáció. Eötvös Loránd Tudományegyetem, Budapest

VASs Z. (2000a) Formai rajzvizsgálat algoritmusokkal: A Psychmet program. Előadáskivonatok. 345. A Magyar Pszichológiai Társaság XIV. Országos Nagygyúlése, Budapest

VASS, Z. (2000b) ESPD: 2000 - Szakértői rendszer projektív rajzok értelmezéséhez [ESPD: 2000 - Expert system for the interpretation of projective drawings]. Elöadáskivonatok. 344. A Magyar Pszichológiai Társaság XIV. Országos Nagygyúlése, Budapest

VASs, Z. (2000c) ESPD: 2000 - Expert System for Projective Drawings. Demonstration Prototype (program). Eötvös Loránd University of Sciences, Budapest

VASS Z. (2000d). Mesterséges intelligencia módszerek a pszichodiagnosztikában. Elöadáskivonatok. 270. A Magyar Pszichológiai Társaság XIV. Országos Nagygyülése, Budapest

VASS Z. (2000e). Szimbólumértelmezés a rajzvizsgálatban (oktatási segédanyag, kézirat). Magyar Relaxációs és Szimbólumterápiás Egyesület, Budapest

VAss, Z. (megjelenés alatt) Perspectives on Objective Assessment of Projective Drawings. Journal of Clinical Psychology

WidlöChER, D. (1965) Was eine Kinderzeichnung verrät. Kindler, München

Wright, J. H., McIntyre, M. P. (1982) The Family Drawing Depression Scale. Journal of Clinical Psychology, 38, 853-861. 


\section{CLINICAL APPLICATION OF KINETIC FAMILY DRAWINGS}

\section{VASS, ZOLTÁN}

The study describes the author's experiences in the clinical application of the Kinetic Family Drawings (KFD). After reviewing history and types of the family drawings, the author points out the most useful interpretations. The application of the KFD is illustrated by a case study which compares three types of the family drawings (Draw-A-Family, Kinetic Family Drawings and Animal Kinetic Family Drawings). Psychometric evaluation (reliability, construct validity) and research perspectives are discussed. The author distinguishes two approaches of the use of KFD: hypothesis-generating instrument and psychometric test. The first approach generates only psychodiagnostic hypotheses to be tested. The second approach requires norms with moderator variables, and carefully planned reliability and validity studies. The basic principles of further studies should be the application of objective evaluation, globalholistic point of view beside of particular characteristics, and analysis of complex, interrelated patterns instead of individual graphic signs. The study concludes that the KFD is a useful instrument in clinical practice and scientific research.

Key words: psychodiagnostics, projective drawings, family drawings, childrens' drawings, Kinetic Family Drawings 